Rakenteiden Mekaniikka (Journal of Structural Mechanics)

vol. 53, nro. 3, 2020, s. 281-303

http://rakenteidenmekaniikka.journal.fi/index

https://doi.org/10.23998/rm.83365

(C) 2020 kirjoittajat

Vapaasti saatavilla CC BY 4.0 -lisenssin mukaisesti

\title{
Hitsiliitoksen geometrian vaikutus väsymismitoituksessa
}

\author{
Lassi Keränen ${ }^{1}$ ja Juhani Niskanen
}

Tiivistelmä Tässä tutkimuksessa tarkasteltiin kahdella eri lämmöntuonnilla MAG-hitsattujen päittäisliitosten geometrian vaikutusta S700-lujuusluokan rakenneteräksen väsymiskestävyyteen lovenvaikutuslukujen avulla. Hitsiliitosten poikkileikkausten geometriat tuotiin elementtimenetelmäohjelmistoon, jossa määritettiin malli lovenvaikutuslukujen laskemiseksi. Laskettuja lovenvaikutuslukuja verrattiin kirjallisuuteen ja lovenvaikutuslukujen avulla määritettiin $S-N$-käyrät, joita verrattiin kirjallisuuden väsytyskoetuloksiin ja mitoitusohjeisiin. Hitsialueen pehmenemisen vaikutuksia väsymiskestävyyteen tarkasteltiin kovuusmittaustulosten perusteella määritetyillä $S-N$-käyrillä. Tutkimuksessa havaittiin, että hitsialueen geometria selittää suuren osan hitsausliitoksen huonommasta väsymiskestävyydestä hitsaamattomaan perusaineeseen verrattuna. Lisäksi havaittiin, että lovenvaikutusluvun, kappaleen koon, kuormitustavan sekä pinnanlaadun vaikutukset huomioiden lujuusopin menetelmällä määritetty $S-N$-käyrä on konservatiivinen vastaavilla MAG-hitsatuilla näytteillä suoritettuihin väsytyskoetuloksiin verrattuna. Esitetty lujuusoppiin perustuva menetelmä näyttää siten antavan kohtuullisia tuloksia edellyttäen, että käytettävä lovenvaikutusluku on määritetty riittävällä tarkkuudella.

Avainsanat: ultraluja teräs, hitsaus, lämmöntuonti, lovenvaikutusluku, jännitysintensiteettikerroin, FEM, väsyminen, murtumismekaniikka

Vastaanotettu: 27.6.2019. Hyväksytty: 13.12.2019. Julkaistu verkossa: 4.9.2020.

\section{Johdanto}

Koneensuunnittelun päämääränä on turvallisesti ja ennalta suunnitellusti toimiva kone tai rakenne. Päämäärän saavuttaminen edellyttää jokaisen komponentin vaurioitumistarkastelua niin, että vaurioitumismekanismi on hallittavissa. Kun kone toimii määritelmänsä mukaisesti, se välittää liikettä tai voimaa, jolloin sen komponentit ovat alttiita vaihtelevan kuormituksen vaikutuksille. Yleisin konerakenteiden vaurio on väsymisvaurio, mikä johtuu juuri vaihtelevasta kuormituksesta. Väsyminen on ilmiö, missä materiaalin alkuviasta, kuten reiän reunasta tai hitsin viasta, kasvaa särö johtaen materiaalin lopulliseen murtumiseen. On havaittu, että kaikista koneiden vaurioista 70-90 \% johtuu materiaalin väsymisestä [1].

\footnotetext{
${ }^{1}$ Vastuullinen kirjoittaja: lassi-pekka.keranen@oulu.fi
} 


\section{Geometrian vaikutukset hitsausliitoksen väsymisessä}

Nguyen ja Wahab [2] sekä Teng, ym. [3] tutkivat hitsatun päittäisliitoksen geometrian ja jäännösjännityksen sekä sovitusvirheen yhdistettyä vaikutusta väsymiskestävyyteen ASTM A36 -teräksellä. Nguyen ja Wahab havaitsivat väsymiskestävyyden paranevan

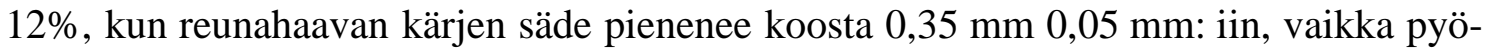
ristyssäteen pienenemisen ajatellaan yleensä pienentävän väsymiskestävyyttä. Reunahaavattoman hitsin väsymiskestävyys on puolestaan lähes $60 \%$ parempi verrattuna hitsiin, jossa on reunahaava.

Teng:n tutkimuksessa puolestaan havaittiin hitsin reunan pyöristyssäteellä olevan poikkileikkauksen geometriamuuttujista suurin vaikutus väsymiskestävyyteen, väsymiskestävyys parani $21 \%$, kun hitsin reunan pyöristyssäde kasvoi arvosta 0 mm kokoon $0,25 \mathrm{~mm}$. Nguyen ja Wahab havaitsivat, että jäännösjännitys heikentää väsymiskestävyyttä huomattavasti vasta, kun vetojäännösjännitys lähenee kyseessä olevan teräksen myötölujuutta. Lisäksi sovitusvirheen vähentäminen $50 \%$ parantaa väsymisrajaa $150 \%$, vaikka reunahaavaa olisi havaittavissa, sillä sovitusvirhe kasvattaa taivutusjännityskomponentin suuruutta ja lovenmuotolukua. Teng, ym. havaitsivat railokulman ja hitsin kylkikulman vaikuttavan jäännösjännitystilan suuruuteen, sillä ne vaikuttavat hitsiaineen määrään. Suurempi määrä kuumaa hitsiainetta aiheuttaa jäähtyessään suuremmat jäännösjännitykset. Kestävyyttä ja kestoikää voidaan siis parantaa poistamalla reunahaava, kasvattamalla reunan sädettä, loiventamalla kylkikulmaa tai jälkikäsittelemällä hitsiliitos muilla tavoin vaikuttamalla esimerkiksi jäännösjännitystilaan.

Sonsino [4] on tutkinut hitsatun rakenteen suorituskykyä olosuhteissa, joissa kuormitustapa, jäännösjännitystila, levyn paksuus ja hitsin geometria vaihtelee. Tutkimuksessa tarkasteltiin S355-, S690- ja S960-lujuusluokkien teräksiä ja liitosmuotoina käytettiin päittäisliitosta, poikittaista jäykistettä, kulmaliitosta sekä limitettyä putken jatkosliitosta. Tutkimuksessa havaittiin, että edullisella geometrialla olevien hitsien kestävyyttä voidaan parantaa pienentämällä jäännösjännitystilaa erityisesti vakioamplitudisessa kuormitustilanteessa. Lisäksi havaittiin, että vetojäännösjännitysten huomiointi Euroopassa käytettyjen suunnitteluohjeiden mukaisesti johtaa konservatiivisiin tuloksiin. Tutkimuksessa todetaan myös, että paikallinen hitsin geometria on tärkein tekijä väsymiskestävyyden parantamisessa, jolloin hitsin geometrian ja kuormitusten tarkasteluun on kiinnitettävä erityistä huomiota. Hitsialueen jäännösjännitystilaan voidaan vaikuttaa IIW:n suositusten $[5,6]$ mukaisesti, mutta tavoiteltu lopputulos edellyttää joka tapauksessa edullista geometriaa.

Shen, ym. [7] tutkivat lämmöntuonnin vaikutuksia hitsipalon geometriaan jauhekaarihitsauksessa molemmilta puolin hitsatuilla päittäisliitoksilla. Tärkeimpänä havaintona oli se, että lämmöntuonnin kasvaessa hitsikuvun korkeus, palon leveys, tunkeuman korkeus ja HAZ-alueen leveys kasvavat sekä hitsipalon kylkikulma pienenee. Suuremmalla lämmöntuonnilla hitsin liittymä perusaineeseen on jyrkempi. Lisäksi havaittiin lineaariset korrelaatiot lämmöntuonnin ja palon leveyden, tunkeuman poikkipinta-alan, kuvun poikkipinta-alan, sulana käyneen poikkipinta-alan sekä kylkikulman välille, joissa lineaarisen sovituksen kulmakertoimina ovat vastaavasti 2,88, 28,45, 21,44, 49,89 ja -15,24. Näiden perusteella poikkipinta-aloilla sekä kylkikulmilla on suurin herkkyys lämmöntuonnin muutokselle. 
Remes \& Varsta [8] ja Liinalampi, ym. [9] ovat tutkineet laser-hybridihitsauksella saatua liitoksen geometriaa, geometrian tilastollista vaihtelua sekä arvioineet hitsiliitoksen geometrian vaikutusta väsymismitoituksessa. Remeksen ja Varstan tutkimuksessa tarkasteltiin $12 \mathrm{~mm}$ teräslevyjen päittäisliitosten geometrian muutoksia laser- ja jauhekaarihitsauksella sekä määritettiin lovenmuotoluvut tilastollinen varmuus huomioiden. Tutkimuksessa havaittiin, että laserhitsausmenetelmissä hitsikuvun kylkikulma ei vaikuta lovenmuotolukuun yhtä vahvasti, kuin kaarihitsausmenetelmissä. Jauhekaarihitsauksen lovenmuotoluvuiksi saatiin 2-2,25, kun laseriin perustuvissa menetelmissä vastaava luku on 1-1,8. Koska muotolukujen vaihteluksi saatiin jopa $35 \%$, tutkimuksessa suositellaan paikallisen geometrian huomioiminen väsymismitoituksessa. Liinalammen, ym. tutkimuksessa tarkasteltiin $3 \mathrm{~mm}$ vahvuisten laser-hybridihitsattujen päittäisliitosten geometriaa FE-menetelmän ja lovijännitysanalyysin avulla. Lovijännitysanalyysissä määritettiin laskentajännitykset eri laskentasyvyyksillä Neuberin säännön mukaisesti ja tulosten perusteella arvioitiin liitosten väsymiskestävyyttä. Lisäksi määritettiin $S-N$-käyrät väsytyskokeiden perusteella. Tutkimuksessa havaittiin laser-hybridihitsauksen tuottavan hyvin kapean hitsin ohuiden levyjen hitsauksessa, joka voi aiheuttaa väsymiskestävyyden huomattavaa heikentymistä aksiaaliseen sovitusvirheeseen yhdistettynä. Lisäksi havaittiin, että hitsiliitoksen geometrian vaikutusta väsymiskestävyyteen voidaan arvioida hyödyntämällä mitattua paikallista geometriaa yhdessä lovijännitysmenetelmän kanssa.

\section{Väsymiskestävyys}

Lujia teräksiä käytettäessä on usein tavoitteena suurempien staattisten kuormitusten salliminen. Jos tavanomaisilla teräksillä määritettyjä väsymisluokkia käytetään kyseisissä tilanteissa, ei lujaa terästä käyttämällä välttämättä saavuteta etuja väsymiskestävyydessä pehmeään teräkseen verrattuna, vaan tilanne voi olla jopa huonompi, johtuen siitä, että staattisen kuormituksen lisäksi rakenteeseen kohdistuu väsyttävää kuormitusta. Tällöin yhteenlaskettu kuormitusheilahdus voi olla aiempaa suurempi, mikä johtaisi lyhyempään kestoikään.

Erityisesti konerakenteissa käytettävien ultralujien terästen hitsausliitosten väsymismitoitusperusteista ei ole vielä yhtenäistä kattavaa tietoa, vaikka väsytyskokeista on raportoitu useissa eri lähteissä. Costa, ym. [10] suorittivat Domex 600 -teräksellä (myötölujuus $670 \mathrm{MPa}$ ) I-railoon MAG-hitsatun päittäisliitoksen väsytyskokeita jännityssuhteella (minimijännitys / maksimijännitys) $\mathrm{R}=0$, jolloin käsittelemättömän hitsiliitoksen suurin sallittu jännitysheilahdus syklimäärällä $2 \cdot 10^{6}$ (väsymisluokka) on $154 \mathrm{MPa}$ (selviytymistodennäköisyys 97,7 \%), kun käyrä piirretään vapaalla kaltevuuskertoimella 5,6. Sorger, ym. [11] vertasivat kitka- ja MAG-hitsattujen päittäisliitosten väsymiskestävyyttä S355- ja S690 -teräksillä. MAG-hitsattujen S690-teräksen päittäisliitoksille saatiin väsymisluokaksi $(97,7 \%) 234 \mathrm{MPa}$ kaltevuuskertoimella $\mathrm{m}=4$,1, kun lämmöntuonnin mukainen jäähtymisaika t8/5 oli $5 \mathrm{~s}$ ja väsytyskokeissa käytettiin jännityssuhdetta $R=0,1$. Nykänen, ym. [12] raportoivat väsytyskokeista Optim 1100 QC teräksellä V-railoon MAG-hitsatuilla näytteillä jännityssuhteella $R=0,05 \ldots 0,12$, jolloin käsittelemättömän liitoksen väsymisluokka (selviytymistodennäköisyys $95 \%$ ) on $189 \mathrm{MPa}$ vapaalla kaltevuuskertoimella 4,83. Vastaava väsymisluokka IIW:n ohjeissa on maksimissaan $112 \mathrm{MPa}$, ja silloin edellytetään hitsin tarkkaa viimeistelyä, hiontaa ja NDT-tarkastusta. 
IIW:n väsymisluokat on määritetty pehmeille teräksille, mutta niitä voidaan käyttää myös lujemmilla teräslaaduilla [6].

Hobbacher [13] ehdottaa hitsausliitosten väsymismitoitusmenetelminä käytettäviksi nimellisen jännityksen, hot spot -jännityksen, ja tehollisen jännityksen menetelmiä sekä murtumismekaniikkaan perustuvia menetelmiä. Radaj et. al. [14] ovat koonneet yhteenvedon nykyisin käytössä olevista hitsin paikallisiin ominaisuuksiin perustuvista väsymislaskentamenetelmistä, joista tunnetuimpia ovat IIW:n mukainen lovijännityksen- tai venymän menetelmä, rakenteellisen jännityksen (hot spot) menetelmä ja modifioitu rakenteellisen jännityksen menetelmä. Lisäksi he esittelevät myös alle $3 \mathrm{~mm}$ paksuille teräksille soveltuvia menetelmiä. Eräs pitkälle kehittynyt väsymismitoitusmenetelmä on Nykäsen ja Björkin [15] kehittämä 3R-menetelmä, mikä huomioi jännityssuhteen, murtolujuuden, loven geometrian ja jäännösjännitystilan väsymiskestävyyden arvioinnissa hyödyntäen lovijännitys, SWT -ja paikallisen venymän menetelmää.

Myös murtumismekaniikkaan perustuvia menetelmiä voidaan käyttää hitsausliitosten väsymismitoituksessa. Murtumismekaniikassa tutkitaan olosuhteita, joissa kuormituksen alainen kappale voi murtua siinä olevan särön tai vian suurenemisen takia. Murtumismekaniikan avulla tutkitaan tyypillisesti rakenteen sallittua särökokoa käyttöönottohetkellä, jäljellä olevaa käyttöikää, kriittistä särökokoa, käyttöaikaa kriittisen särökoon tavoittamiseksi, mahdollisuuksia särön kasvun hidastumiselle tai pysähtymiselle sekä rakenteen tarkastusvälejä [16]. Yksi pitkälle kehittynyt murtumismekaniikan särönkasvumalli on ns. NASGRO-malli, joka on alun perin kehitetty ilmailuteollisuuden tarpeisiin kuvaamaan pitkien säröjen kasvua. Alkuperäinen NASGRO-yhtälö perustuu Formanin ja Mettu:n särönkasvumalliin sekä Newmanin malliin särön sulkeutumisesta ja on Formanin, Newmanin, deKonigin, Henriksenin ja Shivakumarin vuonna 1994 kehittämä [17]. Alkuperäinen NASGRO-yhtälö on esitetty esimerkiksi lähteissä [17,18]. Malli ottaa huomioon keskijännityksen, intensiteettikertoimen kynnysarvon, murtumissitkeyden sekä särön sulkeutumisen vaikutukset särönkasvunopeuteen [17,19]. NASGRO-yhtälö pyrkii siis kuvaamaan särön käyttäytymistä kaikilla kolmella Paris'n särönkasvun alueilla. Maierhofer, ym. [19,20] ovat kehittäneet NASGRO-mallia huomioimaan jäännösjännityksen sekä jännityssuhteen vaikutukset myös lyhyiden säröjen tapauksissa. Yleisesti tiedetään, että lyhyt särö voi edetä myös pitkän särön intensiteettikertoimen kynnysarvoa pienemmillä intensiteettikertoimilla [20,21].

\section{Tutkimusongelma}

Suurin hidaste kehitykselle on se, että terästen kehittyessä nopeasti, ei suunnittelutietämyksen kehitys ole pysynyt kehityksessä mukana [22]. Talonrakennuksen puolella standardi EN 1993-1-12 [23] sallii käytettäväksi maksimissaan 700 MPa myötölujuuden teräksiä, mutta korkeampia lujuusluokkia standardit eivät vielä täysin tunne. Myös osa nykyisten koneenrakennuksen suunnitteluohjeista ja oppikirjoista pohjautuvat edellä mainittuun standardiin ja muihin Eurokoodi 3:n osiin.

Vaikka väsymisilmiö aiheuttaakin suurimman osan vaurioista, on koneenrakennuksessa huomioitava myös muiden suunnitteluperiaatteiden- ja tietämyksen kehitys väsymisilmiön huomioimisen lisäksi. Kun nämä asiat huomioidaan, koneensuunnittelun tavoitteet on mahdollista saavuttaa myös kehittyneitä materiaaleja hyödyntäen. Laadukas materiaali ei siten yksin takaa ensiluokkaista tuotetta, vaan materiaalin tehokas 
hyödyntäminen edellyttää myös suunnitteluosaamista. Nykyisin on tavoitteena parantaa erilaisten koneiden hyötysuhdetta ja kestoikää, mikä tuo tarpeen suunnitella rakenteet yhä kevyemmiksi ja kestävimmiksi [24]. Tällöin suunnittelija valitsee yhä useammin lujan, kehittyneen teräksen kohteisiinsa. Jotta kehittyneestä laadukkaasta teräksestä saadaan kaikki hyöty irti, on rakenteet kyettävä suunnittelemaan mahdollisimman optimaalisiksi sekä luotettavuuden että valmistuksen, asennuksen ja kustannustehokkuuden kannalta.

Tässä artikkelissa tarkastellaan kahdella eri lämmöntuonnilla hitsattua päittäisliitosta erityisesti hitsauksen aiheuttaman epäjatkuvuuden kannalta. Artikkelissa esitetään hitsiliitoksen lovenmuoto- ja vaikutuslukujen laskentaa, jännitysintensiteettikertoimien määritystä sekä hitsiliitoksen väsymistarkastelua lujuusopin menetelmiä hyödyntäen. Tavoitteena on selvittää hitsauksen aiheuttaman geometriamuutoksen vaikutusta hitsiliitoksen väsymiskestävyyteen sekä huomioida hitsialueen pehmentyminen mitoituksessa. Lisäksi tavoitteena on tuoda lisätietoa suunnittelijoille käytännön mitoitusta ajatellen. Aiemmassa tutkimuksessa [24] tarkasteltiin kyntöauran rakenneosien kiinnityskohtien väsymiskestävyyttä pääasiassa standardien (EC3) ja perinteisen lujuusopin menetelmillä. Tässä tutkimuksessa syvennytään kuitenkin tarkastelemaan yksittäistä hitsiliitosta, mikä voisi olla osa esimerkiksi edellä mainittua rakennetta.

\section{Loven vaikutukset hitsausliitoksessa}

Kirjallisuudessa on raportoitu väsytyskokeita ultralujien teräksien hitsausliitoksille ja näiden perusteella on myös kehitetty tarkempia väsymislaskentamenetelmiä [10-12,25]. Väsytystestauksesta poiketen tässä tutkimuksessa tarkastellaan hitsatun liitoksen poikkileikkauksia (Kuva 1.), joiden perusteella tutkitaan liitoksen geometrian vaikutusta perusaineen väsymislujuuteen, väsytyskoetuloksiin ja suunnitteluohjeisiin verrattuna. Kirjallisuustutkimuksen perusteella hitsialueen muotoluvulla on hyvin merkittävä vaikutus väsymiskestävyyteen. Hitsigeometrian parantaminen esimerkiksi poistamalla reunahaava, vähentämällä osien sovitusvirhettä tai muuten parantamalla liitoksen geometriaa voidaan vaikuttaa liitoksen väsymiskestävyyteen huomattavasti. Useissa tutkimuksissa on havaittu, että esimerkiksi hitsin reunan pyöristyssäteen kasvattaminen pienentää lovenmuotolukua, joka puolestaan parantaa väsymiskestävyyttä. Lisäksi on havaittu, että lovenmuotoluku voi vaihdella huomattavasti myös yksittäisen hitsisauman sisällä, jolloin mitoituksessa käytettävän muotoluvun arviointi tulisi tehdä erityisen huolellisesti. Vetojäännösjännityksellä on havaittu olevan suuri vaikutus hitsatun liitoksen väsymiskestävyyteen, mutta kirjallisuustutkimuksen perusteella osa käytössä olevista jäännösjännitysten arviointimenetelmistä voivat olla turhan kriittisiä. Hitsauksessa tuodun lämmön aiheuttamien mikrorakennemuutosten ja jäännösjännitysten vaikutusten tutkiminen jätetään tässä tutkimuksessa tarkastelematta, vaikka etenkin ultralujien terästen tapauksessa niillä voi olla huomattavia vaikutuksia hitsiliitoksen väsymiskestävyyteen $[3,26]$.

\section{Lovenmuoto-ja vaikutusluvut}

Staattisessa mitoitustilanteessa käytetään yleisesti lovenmuotolukua $K_{t}$ kertoimena nimellisjännityksen $\sigma_{\text {nom }}$ ja geometrisen loven aiheuttaman huippujännityksen $\sigma_{\max }$ välillä kaavan 1 mukaisesti: 


$$
\sigma_{\max }=K_{t} \cdot \sigma_{\text {nom }}
$$

Esimerkiksi Rabb on kirjassaan [27] esittänyt lovenmuotoluvun määrittämistä FE-menetelmällä lovettujen väsytyskoesauvojen tapauksessa. Väsymismitoituksessa on käytettävä lovenmuotoluvun sijaan lovenvaikutuslukua $K_{f}$, mikä huomioi geometrisen loven vaikutuksen lisäksi materiaalin lujuuden ja epäjatkuvuuskohdassa olevan loven koon vaikutukset [28]. Lovenvaikutusluku saadaan loviherkkyysluvun $q$ avulla, kaavojen 2 ja 3 mukaisesti:

$$
\begin{gathered}
K_{f}=1+q \cdot\left(K_{t}-1\right), \\
q=\frac{1}{1+a / r},
\end{gathered}
$$

missä $a[\mathrm{~mm}]$ on murtolujuudesta riippuva vakio ja $r[\mathrm{~mm}]$ on loven pohjan säde. Loviherkkyysluvulle on olemassa myös muita määritelmiä, kuin kaavassa 3 esitetään. Lovenvaikutusluvun materiaaliparametrin $a$ arvoja on taulukoitu [28], mutta se voidaan myös laskea kyseessä olevan teräksen murtolujuuden $R_{m}$ perusteella [29], kaava 4. Tällöin parametria $a$ kuvataan termillä $a^{*}$.

$$
a^{*}=0,025 \cdot\left(\frac{2068[M P a]}{R_{m}}\right)^{1,8}
$$

Tässä tutkimuksessa tarkastellaan Strenx 700 MC Plus -rakenneteräksen MAG-hitsattuja päittäisliitoksia. Kyseisen teräksen myötölujuus on vähintään $700 \mathrm{MPa}$ ja murtolujuus 750-950 MPa. Materiaalitoimittajan ainestodistuksen mukaan kyseisen teräksen myötölujuus on $733 \mathrm{MPa}$ ja murtolujuus $832 \mathrm{MPa}$. Hitsaus suoritettiin $6 \mathrm{~mm}$ vahvuisiin levyihin $50^{\circ}$ kulmaan viistettyyn V-railoon MAG-hitsauksena. Hitsauksessa käytettiin kahta eri lämmöntuontia, minimilämmöntuonti oli noin $0,64 \mathrm{~kJ} / \mathrm{mm}$ (jatkossa $\mathrm{Q} 1$ ), mikä on noin $80 \%$ suositellusta maksimiarvosta $0,82 \mathrm{~kJ} / \mathrm{mm}$ kyseisellä teräksellä [30]. Toisena lämmöntuonnin arvona käytettiin noin $0,8 \mathrm{~kJ} / \mathrm{mm}$ (jatkossa Q2), mikä on lähellä sallittua maksimiarvoa.

Hitsatuista liitoksista leikattiin näytteet poikkileikkauksen tarkastelemiseksi. Näytteet hiottiin, kiillotettiin ja etsattiin niin, että liitoksen eri vyöhykkeet saadaan näkyville. Näin valmistellusta näytteestä otettiin valokuva, joka tuotiin Abaqus-ohjelmistoon poikkileikkausprofiilin mallintamiseksi. Kuvassa 1a esitetään pienemmällä ja kuvassa 1b suuremmalla lämmöntuonnilla hitsattujen liitosten poikkileikkaukset sekä mallinnetut poikkileikkauksen ääriviivat. Hitsausliitoksista mitattiin kovuudet mikrokovuusmittausta käyttäen. Kovuusmittauksissa käytettiin $1 \mathrm{~N}$ voimaa, mittaukset tehtiin $1 \mathrm{~mm}$ etäisyydeltä liitoksen yläpinnasta ja mittapisteiden etäisyytenä käytettiin $0,3 \mathrm{~mm}$. Kovuusprofiilit esitetään kuvassa 2, josta nähdään hitsauksen lämmöntuonnin vaikutus HAZ-alueen kovuuteen hyvin selvästi. Suuremmalla lämmöntuonnilla hitsattuna sularajan viereinen HAZ-alue on selvästi pehmentynyt perusaineeseen verrattuna, mutta 3-4 mm etäisyydellä sularajasta on perusainetta kovempi alue. Pienemmällä lämmöntuonnilla hitsattuna HAZ-alue etäisyydellä 0-3 mm on perusainetta kovempaa, jonka jälkeen kovuudet laskevat perusaineen tasolle. 


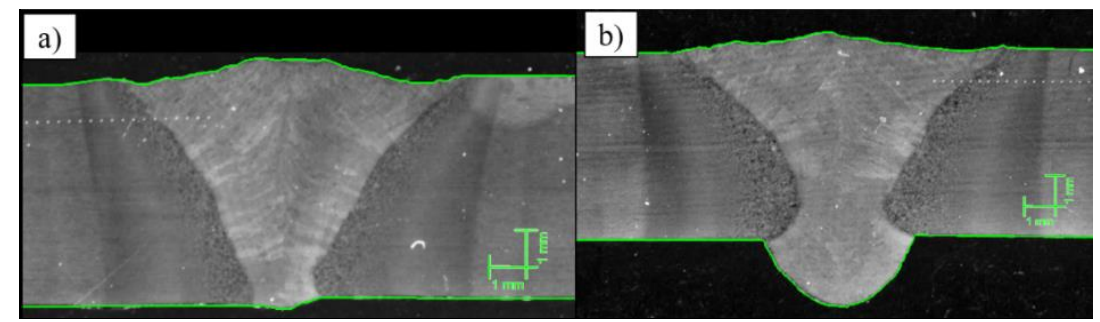

Kuva 1. Liitosten poikkileikkaukset ja mallinnetut ääriviivat, a) Q1 ja b) Q2

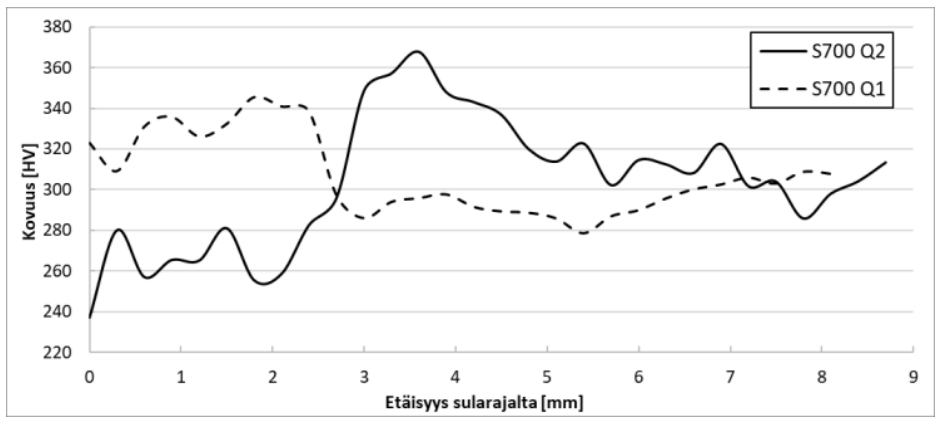

Kuva 2. Hitsausliitosten kovuusprofiilit sularajalta perusaineen suuntaan

Tämä voi johtua esimerkiksi siitä, että pienempää lämmöntuontia käytettäessä jäähtyminen tapahtuu nopeammin, jolloin voi tapahtua karkenemista, mikä näkyy suurempina kovuusarvoina.

Murtolujuutta voidaan arvioida kovuusmittauksista saatujen kovuuden arvojen perusteella. Pavlina ja Van Tyne [31] ovat tutkineet kovuuden sekä murto- ja myötölujuuden vastaavuutta useilla eri teräksillä murtolujuusalueella 450-2350 MPa. Tutkittujen terästen mikrorakenteet olivat ferriittiä, perliittiä, martensiittia, bainiittia tai näiden yhdisteitä. Murtolujuuden ja Vickersin kovuuden välillä havaittiin lineaarinen korrelaatio, jota voidaan kuvata kaavalla 5 seuraavasti:

$$
U T S=-99,8+3,734 \cdot H_{V},
$$

missä UTS on murtolujuus [MPa] ja $H_{V}[\mathrm{HV}]$ on kovuus. Kuvan 2 perusteella matalammalla lämmöntuonnilla hitsatun liitoksen minimikovuus on noin $280 \mathrm{HV}$ ja suuremmalla lämmöntuonnilla $240 \mathrm{HV}$. Kaavalla 5 saadaan näitä vastaaviksi murtolujuuden arvoiksi noin $946 \mathrm{MPa}$ ja $796 \mathrm{MPa}$. Lähteessä [31] on esitetty lineaarinen sovitus myös myötölujuudelle $Y S[\mathrm{MPa}]$, jota kuvaa kaava 6:

$$
Y S=-90,7+2,876 \cdot H_{V} .
$$

Tällöin minimikovuuksien perusteella saadaan myötölujuuksiksi 715 ja $600 \mathrm{MPa}$ matalamman ja korkeamman lämmöntuontien tapauksissa. Lasketut lujuusarvot vastaavat siis teräsvalmistajan ilmoittamia perusaineen lujuusvaihteluita suuremman lämmöntuonnin myötölujuutta lukuunottamatta.

Hitsiliitosten geometria mallinnettiin Catia-mallinnusohjelmalla, josta se siirrettiin Abaqus-laskentaohjelmaan FE-analyysia varten. FE-mallissa käytettiin tukireaktiona niveltukea näytteen vasemmassa päädyssä ja kappaletta asetettiin kuormittamaan $100 \mathrm{MPa}$ vetokuormitus. Tällä menettelyllä ulkoinen kuorma on puhtaasti nimellisjännitykseen 
verrannollista vetokuormitusta. Materiaalimallina käytettiin kimmoista lineaarista mallia kimmokertoimella $210 \mathrm{GPa}$ ja suppeumaluvulla 0,3. Mallin ratkaisussa käytettiin kvadraattista 8-solmuista elementtiverkkoa CPS8R-elementtityypeillä. Elementin sivun mittana käytettiin $0,12 \mathrm{~mm}$, jolloin tällä elementtityypillä laskentapisteitä on $0,06 \mathrm{~mm}$ välein. Laskentamallin tulokset esitetään kuvassa 3 pienemmällä lämmöntuonnilla 0,64 $\mathrm{kJ} / \mathrm{mm}$ hitsatulle liitokselle. Suuremmalla $0,8 \mathrm{~kJ} / \mathrm{mm}$ lämmöntuonnilla hitsatusta näytteestä tehtiin myös FE-malli, jonka ratkaisu esitetään vastaavasti kuvassa 4. Kuvissa 3 ja 4 esitetään pääjännitysten suuruudet siten, että nimellisjännitys $100 \mathrm{MPa}$ vastaa sinistä väriä, nimellisjännitystä matalammat jännitykset esitetään harmaalla värillä ja 150 MPa ylittävät jännitykset punaisella värillä. Lisäksi tarkasteltiin maksimijännitysten herkkyyttä elementtikoon muutokselle ratkaisemalla malli hienommalla elementin sivun mitalla 0,06 mm sekä karkeammalla elementin sivun mitalla 0,6 mm.

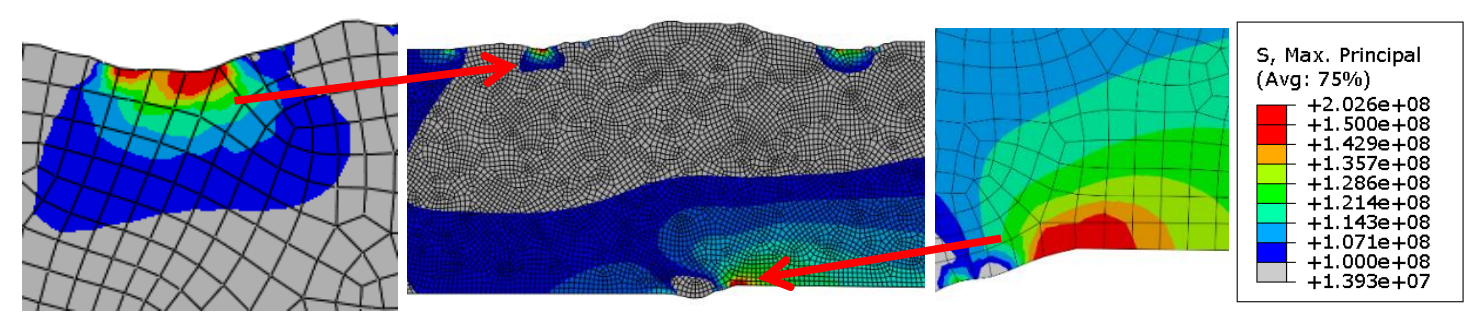

Kuva 3. Laskennan tulokset Q1-poikkileikkauksessa, 0,12 mm elementti, juuren -ja kuvun puolen maksimijännitykset

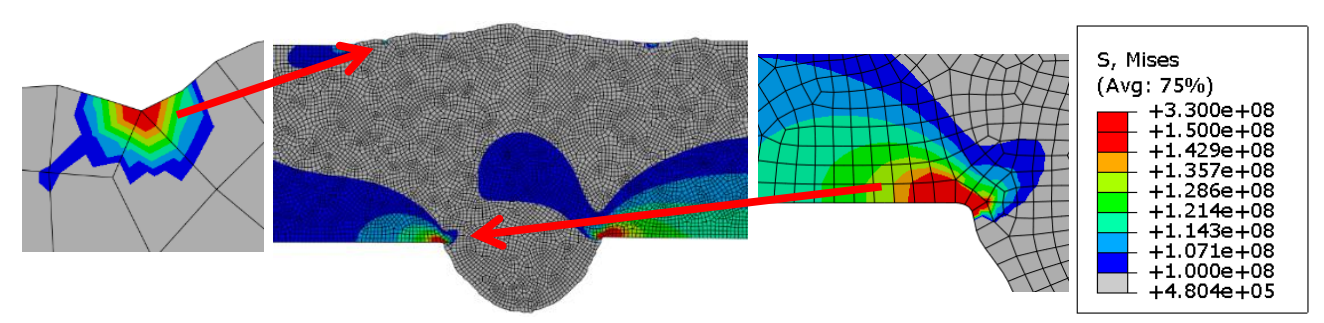

Kuva 4. Laskennan tulokset Q2-poikkileikkauksessa, 0,12 mm elementti, juuren ja kuvun puolen maksimijännitykset

Kuvasta 3 nähdään, että pienemmällä lämmöntuonnilla hitsatun liitoksen jännityksen maksimi löytyy hitsiliitoksen juuren puolelta. Liitoksen kuvun puolella maksimijännitykset löytyvät hitsin reunan alueilta, ollen kuitenkin juuren puolen jännityksiä pienempiä. Kuvan 4 mukaisesti suuremmalla lämmöntuonnilla hitsatun liitoksen maksimijännitykset löytyvät myös juuren puolelta. Suuremmalla lämmöntuonnilla hitsatessa hitsiainetta on tunkeutunut juuren puolelta huomattavasti enemmän ulos matalampaan lämmöntuontiin verrattuna. Tämä aiheuttaa edellistä tilannetta voimakkaamman epäjatkuvuuskohdan hitsiliitokseen, mikä näkyy suurempana juurenpuolen maksimijännityksenä matalamman lämmöntuonnin tapaukseen verrattuna.

Kuvassa 5 esitetään juuren sekä kuvun puolen maksimijännitysalueiden maksimipääjännitysten perusteella lasketut lovenmuotolukujen keskiarvot laskennassa käytetyillä elementtiko'oilla. Keskiarvot laskettiin kolmesta solmupistearvosta, joista keskimmäinen vastasi maksimiarvoa. Lovenmuotoluvut on laskettu kaavalla 1 nimellisjännityksen ja solmupistejännitysten keskiarvon perusteella, jotka on muutettu lovenvaikutusluvuiksi 
kaavalla 5. Tutkitun teräksen murtolujuus on $832 \mathrm{MPa}$, jolloin kaavan 3 parametri a saa arvon 0,14 [28] ja kaavalla 4 laskettuna $a^{*}$ vaihtelee välillä $0,155-0,101$ murtolujuuden minimi- ja maksimiarvoilla laskettuna. Murtolujuudella $832 \mathrm{MPa} \mathrm{a}^{*}: \mathrm{n}$ arvo on 0,129 . Taulukossa 1 esitetään lovenvaikutusluvut laskennassa käytetyt loven pyöristyssäteet, hitsin kylkikulmat sekä eri tavoilla lasketut lovenvaikutusluvut. Parametrin a* suurempi arvo saadaan alempaa murtolujuuden arvoa käyttämällä, mikä johtaa pienempään Kf:n arvoon. Murtolujuudella $750 \mathrm{MPa}$ saadaan a*:1le arvo 0,155 kaavalla 4, jota nyt käytetään lovenvaikutuslukujen laskennassa. Vaihtolujuuden redusoinnissa käytettävän lovenvaikutusluvun Kf laskentakaava saadaan kaavojen 3 ja 4 avulla:

$$
K_{f}=1+\frac{K_{t}-1}{1+a / r} \text {. }
$$

Kestorajaa redusoidaan syklimäärää $N=1000$ vastaavalla lovenvaikutusluvulla $K_{f 1000 \text {, }}$ mikä määritetään loviherkkyysluvun $\hat{q}[28]$ avulla. Kyseessä olevalla S700-teräksellä $\hat{q} \approx 0,3$ ja kestorajaa vastaava lovenvaikutusluku saadaan kaavalla 8:

$$
K_{f 1000}=1+\hat{q}\left(K_{f}-1\right) .
$$

Kuvasta 5 nähdään, että elementtimenetelmän avulla määritetyt lovenmuotolukujen arvot ovat herkkiä elementtikoon muutokselle, sillä elementtiverkon tihentäminen kasvattaa lovenmuotoluvun arvoa nopeasti. Laskentakohtien keskiarvoiset muotoluvut sovitettiin $y=a \cdot x^{b}+c$-muotoiseen funktioon, missä $x$ vastaa elementtikokoa ja y muotolukua. Kun elementtikokoa pienennetään kymmenesosaan 0,6 mm:stä, nähdään, että muotoluvut ja maksimijännitykset nousevat nopeasti etenkin Q2-tilanteessa juuren puolella. Kuvassa 5 esitetään myös käyrä, joka on laskettu kolmella eri elementtikoolla saatujen muotolukujen keskiarvoista. Myös tämä käyrä on muotoa $y=a \cdot x^{b}+c$, missä parametrit saavat arvot $a=0,198, b=-0,507 \mathrm{ja} c=0,95$. Käyrän voidaan ajatella vastaavan hyvälaatuisen päittäishitsin lovenvaikutuslukua, sillä tarkasteltavassa tilanteessa vain suuremmalla lämmöntuonnilla hitsatun näytteen juuren puolen arvot ylittävät keskiarvokäyrän merkittävästi.

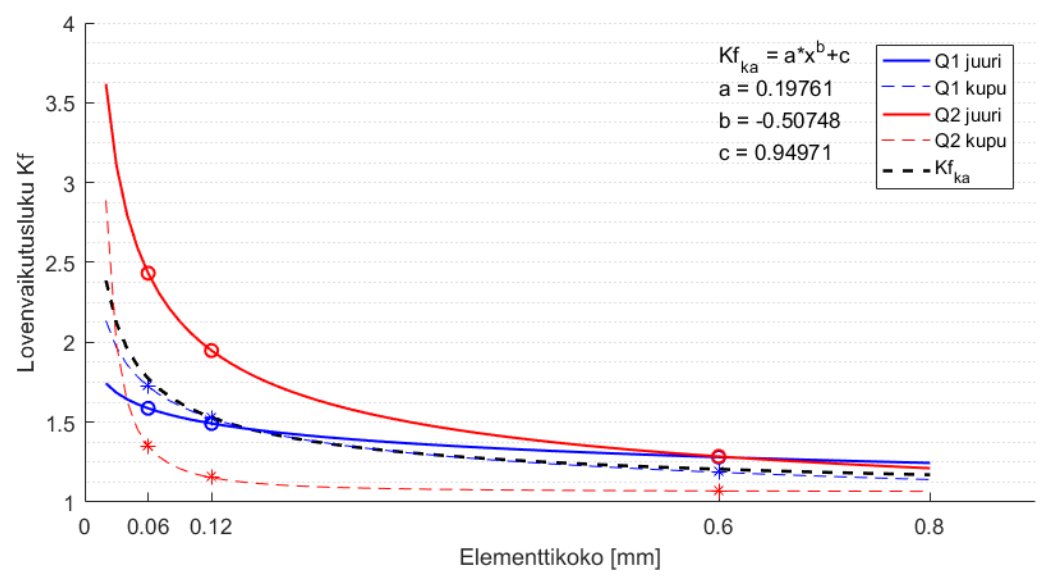

Kuva 5. Lovenvaikutusluvun riippuvuus FE-laskennassa käytetystä elementtikoosta 
Taulukko 1. Lovenvaikutuslukujen vertailua ja loven säteet ja kylkikulmat

\begin{tabular}{lllllll}
\hline Sijainti & säde $\rho$ & kulma $\theta$ & KfFEM \\
& & & $\begin{array}{l}\text { Kf FEM } \\
0,12 \mathrm{~mm}\end{array}$ & $\begin{array}{l}\text { Kf } \\
\text { Lawrence }\end{array}$ & $\begin{array}{l}\text { Kf } \\
\text { Anthes }\end{array}$ \\
\hline Q1 kupu & 0,2 & 20 & 1,52 & 1,72 & 1,647887 & 1,97 \\
Q1 juuri & 0,2 & 14 & 1,49 & 1,59 & 1,591549 & 1,70 \\
Q2 kupu & 0,06 & 38 & 1,15 & 1,35 & 1,708837 & 3,68 \\
Q2 juuri & 0,15 & 79 & 1,95 & 2,43 & 2,263934 & 3,91 \\
Keskiarvo & 0,15 & 37,75 & 1,53 & 1,77 & 1,803052 & 2,82 \\
Kf(95\%) & & & 2,07 & 2,53 & & \\
\hline
\end{tabular}

\section{Lovenmuotoluku kirjallisuudesta}

Lovijännitysmenetelmään liittyen on tehty jonkin verran tutkimusta myös lovenmuotoja vaikutuslukujen laskemiseksi myös hitsiliitoksissa. Radaj, ym. ovat koonneet hitsiliitosten lovenmuotolukujen laskentaa eri lähteiden mukaisesti [29]. Radaj:n mukaan Lawrence, ym. antavat vetokuormitetun päittäisliitoksen hitsin reunan lovenmuotoluvulle kaavan

$$
K_{t, \text { Lawrence }}=1+0,27(\tan \theta)^{1 / 4} \cdot\left(\frac{t}{\rho}\right)^{1 / 2},
$$

missä $\theta$ on hitsin kylkikulma, $t$ on levynvahvuus ja $\rho$ on hitsin reunan pyöristyssäde. Vastaavasti päittäisliitoksella ja pienahitsatulla ristiliitoksella Anthes, ym. antavat lovenmuotoluvulle kaavan

$$
K_{t, \text { Anthes }}=1+\alpha(\sin \theta)^{0,932} \cdot\left(\frac{t}{\rho}\right)^{0,382},
$$

missä $\alpha$ saa arvon 0,728 vetokuormitustilanteessa. Nämä molemmat kaavat on johdettu laskemalla useiden hitsiliitosten muotolukuja FE- ja BE -menetelmillä. Lawrence:n ja Anthes:n kaavojen 6 ja 7 mukaiset lovenmuotoluvut, pyöristyssäteet ja kylkikulmat esitetään taulukossa 1, missä muotoluvut on muutettu lovenvaikutusluvuiksi kaavaa 7 käyttäen. Taulukossa esitetään myös FE-analyysillä lasketut lovenvaikutusluvut $0,12 \mathrm{~mm}$ ja $0,06 \mathrm{~mm}$ elementtikoolla. Taulukosta 1 nähdään, että suuremmalla lämmöntuonnilla hitsatussa näytteessä loven pyöristyssäde on pienempi ja hitsin kylkikulma suurempi, mikä johtaa suurempaan muotolukuun etenkin juuren puolella. Radaj, ym. esittää myös tyypilliset lovenvaikutusluvut päittäishitseille olevan välillä 1,4-1,9 [29]. Myös tässä tutkimuksessa lasketut lovenvaikutuslukujen arvot ovat pääasiassa tällä välillä, lukuun ottamatta 0,6 mm elementtikoolla sekä Anthes:n mukaan laskettuja arvoja.

Kun verrataan taulukon 1 FE-laskennalla $0,06 \mathrm{~mm}$ elementtikoolla saatuja lovenvaikutuslukuja Lawrencen mukaiseen lukuun, nähdään, että lovenvaikutuslukujen keskiarvot ovat lähellä toisiaan. Anthes:n mukaiset lovenvaikutusluvut ovat kuitenkin selvästi suurempia. Erot voivat johtua osin siitä, että Anthes, ym. ovat määrittäneet lovenvaikutusluvut molemmilta puolin hitsatuilla päittäisliitoksilla, kun tässä tutkimuksessa tarkastellaan yhdeltä puolen hitsattua päittäisliitosta. Tämän tutkimuksen perusteella näyttää siltä, että FE-laskennassa tulisi käyttää maksimissaan $0,06 \mathrm{~mm}$ suuruisia kvadraattisia elementtejä todellisen hitsigeometrian muotolukuja laskettaessa, jotta tuloksena 
saatavat muotoluvut vastaavat kirjallisuutta. Taulukossa 1 esitetään myös FE-laskennalla selvitettyjen vaikutuslukujen $95 \%$ selviytymistodennäköisyyttä vastaavat luvut, jotka määritettiin olettamalla lovenvaikutusluvut normaalijakautuneeksi.

\section{Hitsausliitosten väsymismitoitus}

\section{Mitoitus Iujuusopin perusteella}

Määritetään tarkasteltavalle S700-teräkselle $S-N$-käyrä vastaavalla tavalla lujuusopin mukaisesti kuin lähteessä [24] on esitetty. Menetelmä on yleinen kokemukseen perustuva menetelmä, missä väsymiskestävyyttä arvioidaan kyseessä olevan materiaalin murtolujuuden perusteella. Yksinkertaisuutensa vuoksi menetelmä on helppokäyttöinen ja sitä käytetään usein esimerkiksi hitsaamattomien koneenosien alustavassa väsymismitoituksessa. Koska mitoitus perustuu tarkasteltavan teräksen murtolujuuteen, ei laskennassa yleensä huomioida tilastollista vaihtelua. Vaihtelu voidaan kuitenkin huomioida käyttämällä esimerkiksi tiettyä selviytymistodennäköisyyttä vastaava lovenvaikutuslukua. Tällöin kestoraja $\sigma_{1000}$ ja vaihtolujuus $\sigma_{\mathrm{w}}$ saadaan kaavoilla 11 ja 12, kun $S-N$-käyrän suoraa välillä $10^{3} \leq \mathrm{N} \leq 10^{6}$ kuvataan yhtälöllä 13 :

$$
\begin{aligned}
& \sigma_{1000}=0,9 \cdot R m, \\
& \sigma_{w}=0,5 \cdot R m, \mathrm{ja} \\
\log \left(\sigma_{a}\right)-\log \left(\sigma_{1000}\right)= & \frac{\log \left(\sigma_{w}\right)-\log \left(\sigma_{1000}\right)}{\log \left(10^{6}\right)-\log \left(10^{3}\right)} \cdot\left[\log (N)-\log \left(10^{3}\right)\right],
\end{aligned}
$$

missä $R m$ on murtolujuus, $\sigma_{a}$ on jännitysamplitudi ja $N$ kuormitusvaihteluiden määrä. Syklimäärän $10^{6}$ jälkeen $S-N$-käyrä on vaakasuora. Yhtälö 13 voidaan kirjoittaa sievennetyssä yleisessä muodossa, jolloin siitä saadaan kaavan 14 muotoinen:

$$
\sigma_{a}=10^{\alpha} \cdot N^{\beta}
$$

missä

$$
\begin{gathered}
\alpha=\log \left(\sigma_{1000}^{2}\right) \mathrm{ja} \\
\beta=-\frac{1}{3} \cdot \log \left(\frac{\sigma_{1000}}{1,6218 * R m}\right)[28] .
\end{gathered}
$$

Väsymisrajaan vaikuttavina tekijöinä tulee lisäksi ottaa huomioon kappaleen koon, kuormitustyypin, pinnanlaadun, pintakäsittelyn ja ympäristöolosuhteiden vaikutukset, sillä ne voivat vaikuttaa joko väsymiskestävyyttä huonontaen tai parantaen. Tällöin saadaan redusoitu vaihtolujuus $\sigma_{w, r e d}$ kaavan 17 mukaisesti:

$$
\sigma_{w, \text { red }}=\sigma_{w} \cdot\left(\prod c_{i}\right)
$$

missä $c_{i}$ vastaa kertoimia edellä esitettyjen tekijöiden vaikutuksille. Kertoimia on taulukoitu monissa tutkimuksissa ja lujuusopin kirjoissa. Tarkastellaan tämän tutkimuksen hitsiliitoksia lähteen [28] mukaisilla kertomilla: koon vaikutus $c_{1}=1$, kuormituksena aksiaalikuormitus $c_{2}=0,7$ ja kuumavalssattu materiaali $c_{3}=0,53$. Mikäli liitos on hitsatussa 
tilassa, on liitoksen alueella yleensä suuri vetojäännösjännitys, jolloin se aiheuttaa väsymisrajaa pienentävän $\left(c_{4}<1\right)$ kertoimen. Jos liitokseen on saatu tilannetta helpottava puristusjäännösjännitystila, voi kerroin olla suurempi kuin 1.

Kun käytetään terästoimittajan ilmoittamaa murtolujuutta $832 \mathrm{MPa}$, saadaan kaavoista 11 ja 12 arvot $\sigma_{1000}=749 \mathrm{MPa}$ ja $\sigma_{w}=416 \mathrm{MPa}$. Kun vielä redusoidaan kestorajaa ja vaihtolujuutta lovenvaikutusluvuilla $K_{f 1000}$ ja $K_{f}$, jotka saadaan kaavasta 8 ja 0,06 $\mathrm{mm}$ elementtikoolla laskettujen lovenvaikutuslukujen suuren selviytymistodennäköisyyden arvona (taulukko 1) sekä huomioidaan kertoimet $c_{1-3}$ vaihtolujuuden redusoinnissa, saadaan arvot $\sigma_{1000}=513 \mathrm{MPa}$ ja $\sigma_{w, \text { red }}=61 \mathrm{MPa}$. On huomattava, että nämä jännitysten arvot on ilmoitettu jännitysamplitudina. Näiden arvojen ja kaavan 13 mukainen $S-N$-käyrä esitetään kuvassa 9 siten, että käyrän kalteva osa on jatkettu syklimäärään $10^{7}$ saakka ja jännitysamplitudit on muutettu jännitysheilahdukseksi. Tällöin $2 \cdot 10^{6}$ syklimäärää vastaava väsymisluokka on $98 \mathrm{MPa}$ ja kaltevuuskerroin $\mathrm{m}=3,25$. Perinteisen lujuusopin mukaisen $S-N$-käyrän taivekohta asetetaan yleensä syklimäärän $10^{6}$ kohdalle, mikä voi johtaa turhan korkeaan väsymisrajaan tätä suuremmilla syklimäärillä, joten tässä taivekohta jatkettiin kohtaan $10^{7}$.

Määritetään vastaavasti hitsaamattoman perusaineen $S-N$-käyrä lovenvaikutusluvulla 1 koon, kuormitustavan ja pinnanlaadun vaikutukset huomioiden. Lisäksi määritetään käyrät Lawrence:n ja Anthes:n mukaan laskettujen lovenvaikutuslukujen keskiarvoista (taulukko 1) sekä eri lämmöntuonneilla hitsattujen näytteiden minimikovuudesta laskettujen murtolujuuksien perusteella. Käyrät esitetään kuvassa 9 ja väsymisluokat, kaltevuuskertoimet ja mitoitusjännitystä vastaavat kestoiät esitetään taulukossa 2.

\section{Mitoitus nimellisellä jännityksellä}

Nimellinen jännitys on jännitys, joka sisältää rakenneosan muotoilusta riippuvan jännityksen, mutta ei sisällä hitsiliitoksen aiheuttamaa jännitysvaihtelua. Yksinkertaisimmillaan veto-puristus -tilanteessa rakennetta kuormittava nimellinen jännitys lasketaan rakenneosaan kohdistuvan voiman ja rakenneosan poikkipinta-alan osamääränä. Mikäli kyseessä on hitsisauman pitkittäissuuntainen leikkausjännitys, poikkipinta-alana käytetään pienahitsin a-mitan ja pituuden muodostaman tason pinta-alaa. Hitsiliitoksen mitoitus suoritetaan vertaamalla mitoitettavaa liitosta ja sen kuormituksia taulukoituihin rakenneyksityiskohtiin ja niitä vastaaviin väsymisluokkiin, jotka on määritetty väsytyskokeiden perusteella. Kokeissa on siis huomioitu hitsauksen aiheuttamat vaikutukset, kuten jäännösjännitykset, $S-N$-käyrän määrityksessä. Myös Eurokoodi 3 [32] IIW:n lisäksi opastaa väsymismitoitukseen nimellisellä jännityksellä. [6]

Kuvien 3 ja 4 FE-laskennassa käytetty nimellinen jännitys on $100 \mathrm{MPa}$. IIW:n mitoitusohjeen [6] mukaisesti kuormaa kantavan päittäisliitoksen väsymisluokka on maksimissaan $71 \mathrm{MPa}$, kun poikittainen päittäisliitos on hitsattu ilman juuritukea ja juuri on tarkastettu NDT-menetelmin hitsausvirheiden varalta. Väsymisluokka vastaa syklimäärää $2 \cdot 10^{6}$ ja $S-N$-käyrän kaltevuuskerroin on 3 syklimäärään $10^{7}$ saakka, jonka jälkeen käyrä on vaakasuora kaksoislogaritmisella asteikolla. Nimellisen jännityksen mukainen $S-N$ käyrä väsymisluokalla 71 esitetään myös kuvassa 9. FAT 71 -käyrän mukaisesti nimellisellä jännityksellä $100 \mathrm{MPa}$ saadaan vastaavasti kestoiäksi $N=7,2 \cdot 10^{5}$. 


\section{Mitoitus lovijännityksellä}

Lovijännitysmenetelmässä hitsiliitos mallinnetaan käyttäen $1 \mathrm{~mm}$ pyöristyssädettä hitsin reunalla ja juuressa todellisen muodon mallintamisen sijaan, jolloin laskentajännityksistä käytetään nimeä tehollinen lovijännitys. Lovijännitysmenetelmässä käytetään kaikilla liitostyypeillä samaa väsymisluokkaa, mikä on teräksillä FAT 225, ja kaltevuuskerrointa $m=3$ [6]. Yleisessä tapauksessa lovijännitysmenetelmän käyttö rajoittuu hitsatun tilan liitosten tarkasteluun. Laskennassa on lisäksi varmistettava perusaineen kestävyys niin, että lovijännitysmenetelmän mukainen $S-N$-käyrä ei ylitä perusaineen $S-N$-käyrää. Lovijännitysmenetelmän mukainen FAT 225 käyrä esitetään kuvassa 9.

Kuvassa 6 esitetään lovijännitysmenetelmää soveltaen ratkaistut FE-mallit Q1 ja Q2 -liitoksista. Malleissa käytettiin juuren ja kuvun korkeutena ja leveytenä todellisesta geometriasta saatuja juuren ja kuvun mittoja sekä lovijännitysmenetelmän mukaista pyöristyssädettä $r=1 \mathrm{~mm}$. Elementteinä käytettiin 8-solmuisia CPS8R-elementtejä sivunmitalla 0,25 mm. Kuten kuvasta 6 nähdään, on pääjännitysten maksimiarvot juuren puolella sekä suuremmalla että pienemmällä lämmöntuonnilla hitsatuissa liitoksissa. Pienemmän lämmöntuonnin tilanteessa maksimijännitys on $147 \mathrm{MPa}$ ja suuremman lämmöntuonnilla $186 \mathrm{MPa}$.

Päittäisliitos mallinnettiin $6 \mathrm{~mm}$ paksuisilla levyillä lovijännitysmenetelmän mukaisesti siten, että juurikuvun leveytenä käytettiin $1 \mathrm{~mm}$ ja railokulmana 50 astetta sekä kuvun ja juuren liittymäkohtien pyöristyssäteinä $1 \mathrm{~mm}$. Lovijännitysmenetelmässä hitsin kylkikulmana tulisi käyttää $30^{\circ}$ [6]. Kyseisellä kulmalla hitsikupujen korkeudet ovat tässä tapauksessa standardin SFS-EN ISO 5817 [33] mukaisen hitsiluokan B sallittuja korkeuksia pienempiä, jolloin laskenta voi johtaa hitsiluokan B mukaista sallittua geometriaa pienempiin jännityksiin. Lovijännitykset laskettiin siten standardin kupujen korkeuksien maksimiarvoja käyttäen, jotta ne vastaavat pahinta sallittua tilannetta. Kun verrataan toteutunutta geometriaa standardiin SFS-EN ISO 5817, näyttää Q1-liitos täyttävän hitsiluokan B vaatimukset. Q2-liitos ei täytä hitsiluokan B vaatimuksia, sillä juurikuvun korkeus ylittää sallitun korkeuden sekä kuvun liittymiskulma on sallittua jyrkempi. Tämän laskennan tulokset esitetään kuvassa 7. Lovijännitysmenetelmän mukaisesti laskettu maksimijännitys on edellisistä ratkaisuista poiketen kuvun puolella, ollen $171 \mathrm{MPa}$, kuten kuvassa 7 esitetään.

Kun verrataan todellisen geometrian perusteella ratkaistuja lovijännityksiä suositusten [6] mukaisella tavalla ratkaistuihin lovijännityksiin, nähdään, että todellisesta geometriasta riippuen jännitys voi erota teorian mukaisesti lasketusta jännityksestä suhteellisen paljon. Mitoitusta tehdessä on myös huomioitava, että maksimijännitys voi löytyä joko juuren tai kuvun puolelta. Nimellisjännityksen ollessa $100 \mathrm{MPa}$ ja laskettaessa lovijännitys todellisesta geometriasta, saadaan maksimijännitykseksi 186 MPa. FAT 225 -käyrän mukaisesti tämä jännitys antaa kestoiän $N$ arvoksi noin 3,5·10 


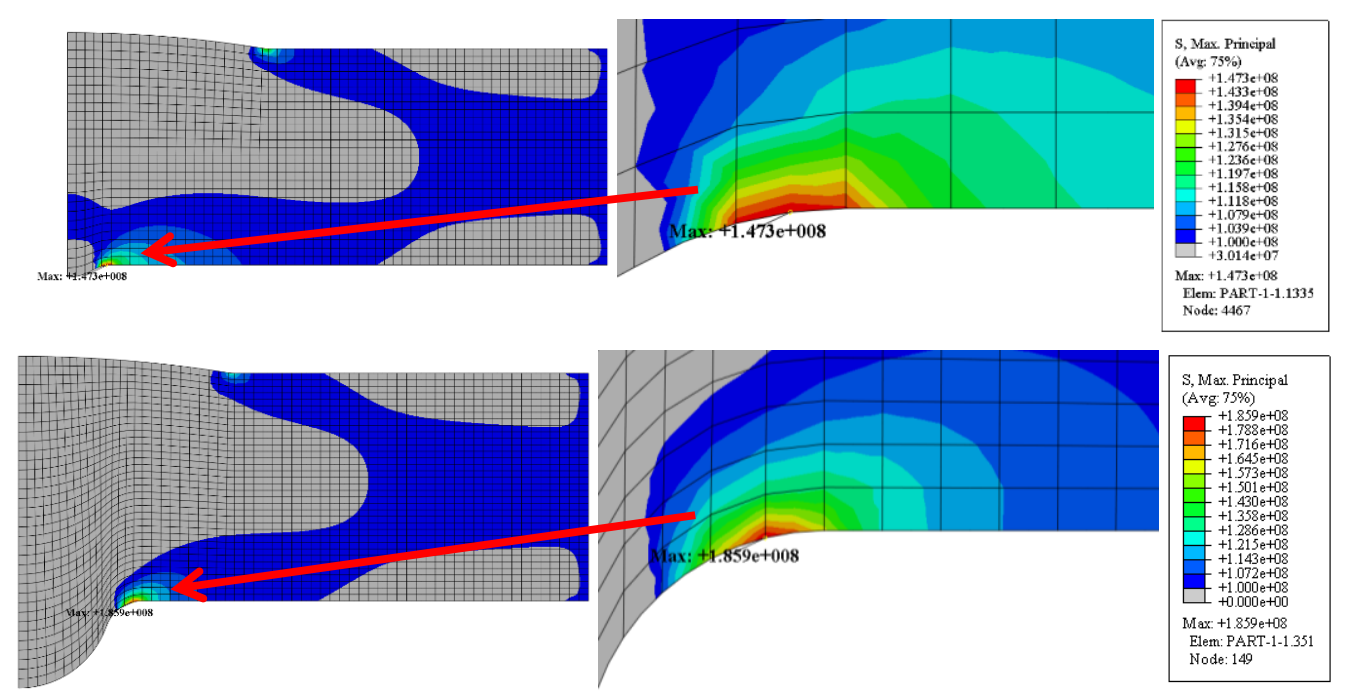

Kuva 6. Todellisen geometrian ja lovijännitysmenetelmän yhdistäminen FE-analyysissä, ylähäällä pienempi ja alhaalla suurempi lämmöntuonti

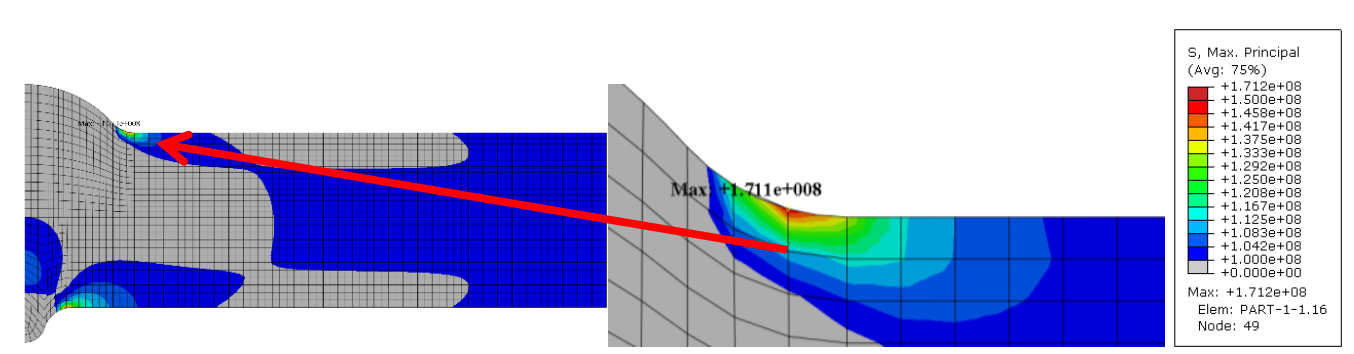

Kuva 7. Päittäisliitoksen lovijännitysten laskenta, kun hitsin kupujen korkeudet ovat standardin SFS-EN ISO 5817 mukaisessa hitsiluokan B maksimiarvossa

\section{Mitoitus murtumismekaniikan avulla}

Hitsiliitosten mitoitus murtumismekaniikan avulla perustuu jännitysintensiteettikertoimiin $K$ [6], jotka voidaan laskea numeerisesti tai kirjallisuudesta löytyvien laskentakaavojen avulla. Myös intensiteettikertoimilla väsymismitoitus voidaan tehdä joko äärettömälle tai äärelliselle kestoiälle. Jännitysintensiteettikertoimien laskentakaavoja esitetään monissa eri lähteissä eri särögeometrioiden ja kuormitustapausten perusteella, esimerkiksi kuormaa kantaville päittäishitsiliitoksille löytyy laskentakaavat lähteistä [6] ja [34]. Mikkola, ym. ovat esittäneet menetelmän $S-N$-käyrän määrittämiseksi ekvivalentin alkusärön perusteella, missä ekvivalentti särökoko riippuu tarkasteltavasta geometriasta tai alkuviasta [35]. Kyseisessä tutkimuksessa $S-N$-käyrät määritettiin kuormaa kantamattomille pitkittäiselle rivalle ja ristiliitokselle.

Jännitysintensiteettikerroin voidaan laskea myös FE-menetelmällä. Lisäksi mitoitus voidaan tehdä esimerkiksi J-integraalin ja särön kärjen avauman perusteella. Kuormitustilanteessa I teräksillä yleinen murtumaan johtava jännitysintensiteettikertoimen kynnysarvo on noin 4-8 MPa $\sqrt{\mathrm{m}}$ [16] ja hitsiliitoksilla suunnitteluohjeessa [6] käytetään jännitysintensiteettikertoimen vaihtelun kynnysarvona $\Delta K_{t h}=2 \mathrm{MPa} \sqrt{ }$. Mikäli havaittu intensiteettikertoimen vaihtelun arvo on kynnysarvoa pienempi, oletetaan että särö ei kasva. Tällöin kyse on äärettömän kestoiän mitoituksesta ja tilanteesta, jossa kappale ei 
murru kuormituksen pysyessä samana. Mitoitusohjeen [6] mukaan intensiteettikertoimen heilahdus $\Delta K$ voidaan laskea kaavalla

$$
\Delta K=\sqrt{\pi \cdot a} \cdot\left(\sigma_{m} \cdot Y_{m} \cdot M_{k, m}+\sigma_{b} \cdot Y_{b} \cdot M_{k, b}\right),
$$

missä $a[\mathrm{~mm}]$ on särökoko, $K$ on intensiteettikerroin, $\sigma_{m}[\mathrm{MPa}]$ on kalvojännitys, $\sigma_{b}$ [MPa] on taivutusjännitys, $Y_{m}$ on korjausfunktio kalvojännityksen intensiteettikertoimelle, $Y_{b}$ on korjausfunktio taivutusjännityksen intensiteettikertoimelle, $M_{k, m}$ on korjaustermi epälineaariselle kalvojännityspiikille ja $M_{k, b}$ on korjaustermi epälineaariselle taivutusjännityspiikille. Korjausfunktiot ja -termit riippuvat kuormitustapauksesta sekä tarkasteltavasta geometriasta. Lähteessä [34] esitetään kuormitustapaukselle I intensiteettikertoimen heilahduksen laskentakaava

$$
\Delta K_{I}=\sqrt{\pi \cdot a} \cdot\left(\frac{\sigma_{m} \cdot Y_{m} \cdot M_{k, m}+\sigma_{b} \cdot Y_{b} \cdot M_{k, b}}{\phi}\right),
$$

missä $\phi$ riippuu laskentasärön syvyydestä $a[\mathrm{~mm}]$ ja särön leveydestä $c[\mathrm{~mm}]$ seuraavasti [34]:

$$
\phi=\sqrt{1+1,464 \cdot\left(\frac{a}{c}\right)^{1,65}} .
$$

Mikäli havaittu jännitysintensiteettikerroin on kynnysarvoa suurempi, särö kasvaa. Tällöin mitoitus tehdään äärellisen kestoiän alueella ja kestoikä riippuu materiaalista, kuormituksesta ja alkusärön koosta. Hitsiliitoksessa oletetaan yleensä aina olevan alkusäröjä. Äärellisen kestoiän tapausta kuvataan usein ns. Paris'n lailla. Kestoikä tietyllä jännitysamplitudilla $\sigma_{a}$ voidaan johtaa murtumismekaniikan avulla sijoittamalla jännitysintensiteettikertoimen vaihteluväli $\Delta K$ (kaava 21) Paris'n lakiin (kaava 22) ja ratkaisemalla syklimäärä $N$ integroimalla lauseke särön alkupituuden $a_{0}$ ja kriittisen pituuden $a_{c}$ välillä:

$$
\begin{gathered}
\Delta K=F \cdot \Delta \sigma_{a} \cdot \sqrt{\pi \cdot a} \\
\frac{d a}{d N}=C(\Delta K)^{m} \\
\int_{a_{0}}^{a_{c}} \frac{d a}{d N}=C\left(F \cdot \Delta \sigma_{a} \cdot \sqrt{\pi \cdot a}\right)^{m} d a \\
N=\frac{1}{C\left(F \cdot \Delta \sigma_{a} \cdot \sqrt{\pi}\right)^{m}} \cdot \int_{a_{0}}^{a_{c}} a^{-\frac{m}{2}} d a=\frac{1}{C\left(F \cdot \Delta \sigma_{a} \cdot \sqrt{\pi}\right)^{m}}\left(-2 \cdot \frac{a_{c}^{\frac{-m+2}{2}}}{m+2}+2 \cdot \frac{a_{0}^{\frac{-m+2}{2}}}{m+2}\right) \\
\rightarrow N=C^{-1}(F \cdot \sqrt{\pi})^{-m}\left(\frac{2 a_{0}^{1-\frac{m}{2}}}{m+2}-\frac{2 a_{c}^{1-\frac{m}{2}}}{m+2}\right) \cdot \Delta \sigma_{a}^{-m}
\end{gathered}
$$

missä $F$ on vakioksi oletettu muototekijä, $\Delta \sigma_{a}$ on jännitysamplitudi, $d a / d N$ on särönkasvunopeus, $C$ ja $m$ ovat materiaalivakioita, ja $N$ on syklimäärä. Mikäli kaavan 21 materiaalivakioiden arvoja ei tunneta, voidaan ferriittis-perliittisillä teräksillä käyttää arvoja $C=6,9 \cdot 10^{-12} \mathrm{MPa} \sqrt{\mathrm{m}}$ ja $m=3,0$ sekä vastaavasti martensiittiselle teräkselle 
$C=1,35 \cdot 10^{-10}$ ja $m=2,25$ [16]. IIW:n suosituksissa [6] annetaan teräksen hitsiliitoksille vastaavasti arvot $C=1,65 \cdot 10^{-11}$ ja $m=3$. Vaihtolujuuden arvo saadaan selville seuraavasti, kun jännitysintensiteettikertoimen vaihteluväli oletetaan kynnysarvon suuruiseksi:

$$
\sigma_{w}=\frac{\Delta K_{t h}}{F \sqrt{\pi \cdot a_{0}}},
$$

missä $a_{0}$ on särön alkupituus [16]. Kriittinen särökoko riippuu käytettävän materiaalin murtumissitkeydestä sekä tilanteessa vaikuttavasta jännityksen suuruudesta. Kriittisen särön koko voidaan ratkaista kaavasta 26 , kun intensiteettikertoimen vaihteluvälin $\Delta K$ suuruudeksi asetetaan kyseisen materiaalin murtumissitkeys $\Delta K_{C}$ :

$$
a_{c}=\left(\frac{\Delta K_{C}}{F \cdot \Delta \sigma \cdot \sqrt{\pi}}\right)^{2}
$$

Jos käytetään arvoa $\Delta K_{C}=50 \mathrm{MPa} \sqrt{\mathrm{m}}$, saadaan kriittiseksi särökooksi noin $37 \mathrm{~mm}$, kun muototekijä lasketaan lähteissä [6,34] päittäisliitokselle esitetyllä tavalla puolielliptisen pintasärön tapauksessa ja käytetään jännitysheilahdusta $\Delta \sigma=100 \mathrm{MPa}$. $F$ laskettiin olettamalla särön alkupituuden olevan $0,3 \mathrm{~mm}$, mikä vastaa silmin havaittavan reunahaavan syvyyttä. Tällöin $F:$ n arvoksi saadaan noin 1,47. Kun tarkastellaan kaavalla 25 saatua laskennallista kriittistä särökokoa, huomataan sen olevan hyvin suuri verrattuna tässä tutkimuksessa käytettyyn levynvahvuuteen nähden. Alkusärön koko $a_{0}$ on kuitenkin huomattavan paljon kriittistä särökokoa merkittävämpi kestoiän määrittämisessä, eikä laskentatulos merkittävästi muutu, vaikka kriittisenä särökokona käytettäisiin ääretöntä kaavassa 23. Tämä johtuu siitä, että lähestyessä murtumissitkeyden arvoa särön kasvunopeus kasvaa voimakkaasti.

Nyt $F$ :n oletetaan pysyvän vakiona ja vastaavan alkutilannetta, vaikka todellisuudessa se riippuu myös alkusärön koosta. Siten särön kasvaessa myös $F$ muuttuu. Todellisessa mitoitustehtävässä on tehtävä ohjelma, joka laskee kertoimen $F$ uudestaan jokaisen säröä kasvattavan syklin jälkeen, jotta mitoitus toimisi mahdollisimman tarkasti.

Sijoittamalla korjauskerroin $F$ jännitysintensiteettikertoimen laskentakaavaan, saadaan laskettua intensiteettikertoimen arvo, mikä on tarkasteltavassa tilanteessa noin 4,5 MPa $\sqrt{\mathrm{m}}$. Nyt intensiteettikerroin on kynnysarvoa suurempi, jolloin särö kasvaa ja johtaa kuormitusten jatkuessa murtumaan. Murtuma tapahtuu viimeistään silloin, kun intensiteettikerroin on kyseessä olevan materiaalin murtumissitkeyden suuruinen. Kestoikä saadaan selville kaavan 24 avulla, kun alkusärön koko, kriittinen särökoko, jännitysamplitudi sekä termit $F, C$ ja $m$ ovat tiedossa. Kun käytetään arvoja $a_{0}=0,3 \mathrm{~mm}, a_{c}=37$ $\mathrm{mm}, \Delta \sigma_{a}=50 \mathrm{MPa}, F=1,47, C=1,65 \cdot 10^{-11}$ ja $m=3$ saadaan kestoiäksi $\mathrm{N}=5756034$.

Yleensä mitoitustilanteessa on ennalta määrätty kestoikä, mikä tulisi täyttyä. Tällöin alkusärön koko on määräävä tekijä kestoiälle. Kun mitoitettavan yksityiskohdan muototekijä $F$ on tiedossa ja oletetaan vakioksi, voidaan laskea kestoikä alkusärön koon funktiona kaavalla 24. Tällöin saadaan selville alkusärön hyväksyttävissä oleva maksimikoko, jotta vaadittu kestoikä täyttyy. Maksimisärökokona on tässä käytetty kaavalla 26 laskettua arvoa. Kuvassa 8 esitetään käyrä, jossa on vaaka-akselilla kestoikä ja pystyakselilla alkusärön koko. Kyseinen käyrä koskee ainoastaan tässä tutkimuksessa esitettyä päittäisliitosta $100 \mathrm{MPa}$ nimellisellä jännityksellä kuormitettuna. Mikäli halutaan määrittää vastaava käyrä toiselle tilanteelle, on määritettävä tekijä $F$ uudelleen. 


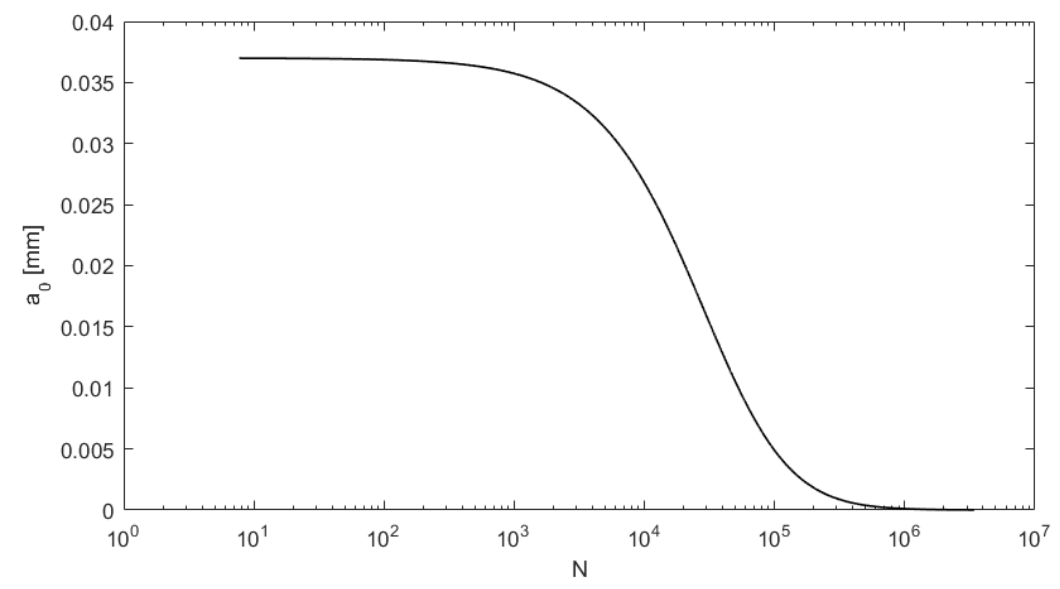

Kuva 8. Suurin sallittu alkusärön koko millimetreinä kestoiän funktiona tämän tutkimuksen hitsiliitoksella $100 \mathrm{MPa}$ jännitysheilahduksella.

\section{Tulosten tarkastelu}

Tutkimuksessa selvitettiin kahden eri lämmöntuonneilla hitsattujen päittäisliitosten lovenmuoto- ja vaikutusluvut FE-menetelmää ja kirjallisuutta hyödyntäen. FE-menetelmällä tiheällä elementtiverkolla lasketut lovenvaikutusluvut vastaavat hyvin Lawrence:n lovenvaikutuslukua. Anthes:n mukaan lasketut lovenvaikutusluvut ovat kuitenkin muita lovenvaikutuslukuja suurempia erityisesti suuremman lämmöntuonnin tapauksessa. Tiheällä elementtiverkolla määritetty $95 \%$ selviytymistodennäköisyyttä vastaava lovenvaikutusluku 2,53 on kuitenkin lähempänä Anthes:n mukaan laskettuja lukuja. Lovenvaikutuslukuja käytettiin $S-N$-käyrän arvioinnissa redusoimalla kestorajaa ja vaihtolujuutta lovenvaikutusluvuilla, jolloin huomioidaan geometrian vaikutus rakenneyksityiskohdan maksimijännitykseen siten, että kestoikä voidaan määrittää nimellisellä jännityksellä. Lisäksi vaihtolujuuden redusoinnissa huomioitiin koon, kuormitustavan sekä pinnanlaadun vaikutukset.

Kuvassa 9 esitetään tässä tutkimuksessa määritetyt $S-N$-käyrät perusaineelle ja hitsatulle päittäisliitokselle S700 teräksellä. Näiden käyrien määritys perustui perinteisen lujuusopin mukaiseen $S-N$-käyrien määrittämiseen murtolujuuden perusteella, jossa huomioitiin koon, kuormituksen ja pinnanlaadun sekä lovenvaikutuslukujen vaikutukset vaihtolujuutta pienentävänä tekijänä. Kuvasta nähdään, että perusaineen murtolujuuden perusteella määritetyn $S-N$-käyrän väsymisraja on noin $182 \mathrm{MPa}$, kun koon, kuormitustavan ja pinnanlaadun vaikutukset on huomioitu. Kun tätä käyrää verrataan samalla murtolujuudella määritettyyn hitsausliitoksen $S-N$-käyrään, missä myös lovenvaikutusluvut on huomioitu, havaitaan, että perusaineen väsymisraja on noin 3,03-kertainen. Tämä tarkoittaa sitä, että päittäishitsatun liitoksen geometria pienentää hitsatun liitoksen väsymisrajan noin $33 \%$ : iin hitsaamattoman perusaineen väsymisrajaan verrattuna, kun lovenvaikutuslukuna käytetään $95 \%$ selviytymistodennäköisyyttä vastaavaa lukua.

Anthes:n mukaisella lovenvaikutusluvun keskiarvolla määritetty $S-N$-käyrä on lähellä hitsiliitoksen pehmeimmän kohdan mukaan määritettyä $S-N$-käyrää sekä väsymisrajaltaan että kaltevuudeltaan, sillä väsymisraja on noin $8 \%$ pienempi kuin $240 \mathrm{HV}$ kovuutta ja lovenvaikutuslukua 2,53 vastaava väsymisraja. Lawrencen keskimääräisellä 
lovenvaikutusluvulla saadaan puolestaan hieman loivempi käyrä, jolloin väsymisraja on noin $31 \%$ suurempi kuin $280 \mathrm{HV}$ kovuuden käyrällä. Tämän perusteella Anthes:n mukaiset lovenvaikutusluvut ovat mitoituksessa varmalla puolella. Kovuuksilla $240 \mathrm{HV}$ ja $280 \mathrm{HV}$ väsymisrajat ovat $31 \%$ ja $37 \%$ perusaineen väsymisrajasta, kun lovenvaikutusluvut ja koon, pinnanlaadun sekä kuormitustavan vaikutukset on huomioitu.

Kuvassa 9 esitetään myös mitoitusohjeiden mukaiset nimellistä- ja lovijännitystä vastaavat $S-N$-käyrät kyseiselle liitosmuodolle sekä aiempien tutkimusten väsytyskoetuloksien [10-12] mukaiset käyrät hitsatuille Domex 600, S690 ja S1100 teräksille. Kun verrataan hitsausliitoksen minimimurtolujuuksista määritettyjä käyriä mitoitusohjeen FAT 71 -käyrään, on murtolujuuksista laskettujen käyrien väsymisrajat 38-64 \% suurempia. S690-teräksen päittäisliitosten $S-N$-käyrän väsymisraja on kuitenkin noin 2,63-kertainen tässä tutkimuksessa $95 \%$ lovenvaikutusluvun selviytymistodennäköisyydellä määritettyyn käyrään verrattuna. Domex 600 ja S1100 -teräksillä päittäisliitosten väsymisrajat ovat hieman matalampia S690-teräksen päittäisliitokseen verrattuna. Aiempien tutkimusten väsytyskokeiden $S$ - $N$-käyrien kaltevuuskertoimet ovat suurempia kuin tässä tutkimuksessa määritetyillä käyrillä, mikä tarkoittaa sitä, että lujuusopin mukaiset käyrät sallivat suurempia jännitysvaihteluita pienillä syklimäärillä ja päinvastoin.

Suurempi lovenmuotoluku tarkoittaa jyrkemmin laskevaa $S-N$-käyrää eli pienempää kaltevuuskerrointa $m$. Tämä johtuu siitä, että lujuusopin mukaisesti kestorajan lovenvaikutusluku lasketaan vaihtolujuutta vastaavasta lovenvaikutusluvusta. Pienillä kuormanvaihtokerroilla lovenvaikutusluvulla ei siis ole yhtä suurta vaikutusta sallittuun jännitysheilahdukseen korkeaan syklimäärään verrattuna.

Taulukossa 2 esitetään kuvan 9 mukaisten $S-N$-käyrien väsymisrajat $\Delta \sigma_{w}$, kaltevuuskertoimet $m$, jännitysheilahduksen $\Delta \sigma$ suuruudet syklimäärän $2 \cdot 10^{6}$ kohdalla, käyrää vastaavat mitoitusjännitykset $\Delta \sigma_{d}$ sekä kestoikä sykleinä $N$ mitoitusjännityksellä. Lisäksi taulukossa esitetään myös murtumismekaniikan avulla määritetty väsymisraja ja kestoiät, kun nimellinen jännitysheilahdus on $100 \mathrm{MPa}$. Tällä jännitysheilahduksella mitoitettuna Domex 600, S690 ja S1100 -terästen päittäishitseille saadaan ääretön kestoikä. Mikäli kyseiset käyrät pakotettaisiin esimerkiksi suunnitteluohjeiden mukaiseen kaltevuuskertoimeen 3, väsymisraja olisi matalampi. Murtolujuuksien ja lovenvaikutuslukujen perusteella määritettynä kestoiät $100 \mathrm{MPa}$ jännitysheilahduksella ovat noin 2,3-4 -kertaisia FAT 71 mukaiseen kestoikään verrattuna. Anthes:n ja Lawrence:n käyrien mukaiset kestoiät ovat FAT 71: n kestoikään verrattuna noin 1,9 ja 9,4 -kertaisia. Murtumismekaniikan avulla saatu kestoikä on jo lähes 20 \% FAT 71 mukaista kestoikää pienempi, ollen siten tässä tarkastelluista laskentatavoista konservatiivisin. Lovijännityksellä $186 \mathrm{MPa}$ laskettuna käyrä FAT 225 antaa noin viisinkertaisen kestoiän FAT 71 mukaiseen käyrään verrattuna. Yleisesti lovijännitysmenetelmän katsotaan antavan tarkkoja tuloksia, mutta tarkasteltavassa tilanteessa lovijännitysmenetelmällä saatiin huomattavasti suurempi kestoikä muihin menetelmiin verrattuna.

Murtumismekaaniset menetelmät normaalissa koneensuunnittelun väsymismitoituksessa vaativat paljon laskentaa joko käsin tai tietokoneella tehtynä. Suurin hyöty murtumismekaniikasta saadaan siten tilanteessa, jossa on määritettävä suurin vikakoko, joka voidaan tuotteessa sallia. Tämä edellyttää kappaleen NDT-tarkastusta, jotta sallittua suuremmat viat voidaan korjata tai kappale hylätä. Varsinainen mitoitus voidaan kuitenkin tavanomaisessa tilanteessa tehdä helpommilla menetelmillä. 
Koska S690-teräs on ominaisuuksiltaan hyvin lähellä tässä tutkimuksessa käytettyä S700-terästä, näyttää lovenvaikutusluvun, murtolujuuden ja muiden pienennystekijöiden perusteella laskettu $S-N$-käyrä olevan mitoituksessa varmalla puolella koetuloksiin verrattuna, vaikka esimerkiksi jäännösjännitysten merkitystä ei huomioitu. Liitosalueella hitsauksen aiheuttama pehmeneminen huomioitiin määrittämällä $S-N$-käyrä liitosten matalimpien kovuuksien perusteella yhdessä lovenvaikutusluvun kanssa. Pienemmän lämmöntuonnin tapauksessa näin saatiin suurempi väsymisraja perusaineen murtolujuudella määritettyyn käyrään verrattuna. Tässä tutkimuksessa lovenvaikutusluvut mitattiin kuitenkin vain yhdestä poikkileikkauksesta kahdella eri liitoksella, joiden perusteella määritetiin yhteinen suuren selviytymistodennäköisyyden lovenvaikutusluku. Hitsisauman geometria voi kuitenkin vaihdella, jolloin lovenvaikutusluku ei ole sama kaikkialla kyseisessä liitoksessa. Tällöin hitsiliitoksen laadusta tulisi varmistua etenkin rakenteen kriittisissä kohdissa, jotta lovenvaikutusluvun avulla voidaan tehdä esimerkiksi alustavia arvioita hitsausliitoksen väsymiskestävyydestä.

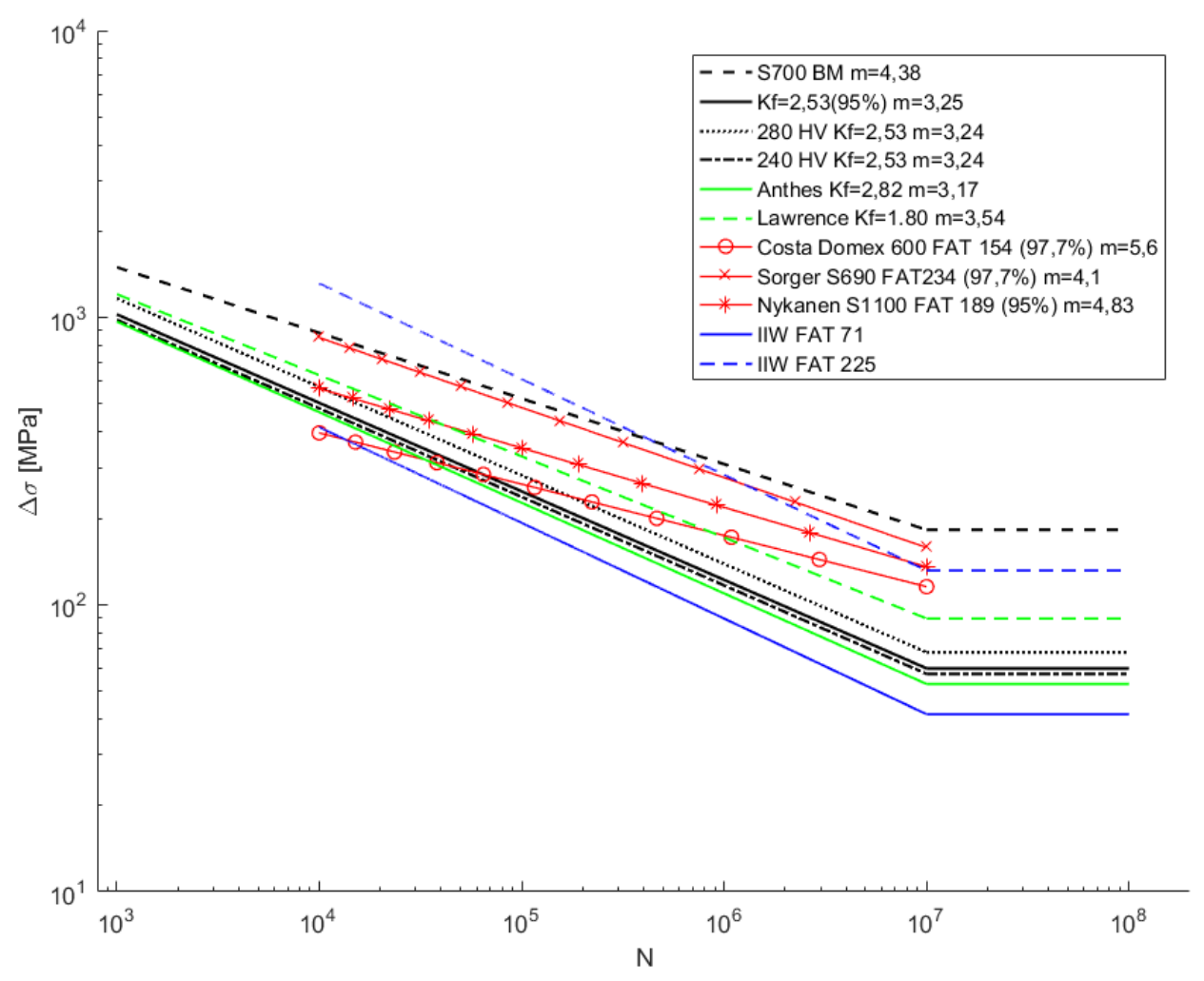

Kuva 9. Geometrian, kovuusmittaustulosten sekä kirjallisuuden mukaan lasketuilla lovenvaikutusluvuilla piirretyt $S-N$-käyrät ja niiden vertailu liitostyyppiä vastaaviin väsytyskoetuloksiin ja suunnitteluohjeisiin. 
Taulukko 2. Eri laskentamenetelmien väsymisrajat, käyrän kaltevuuskertoimet, väsymisluokat, mitoitusjännitykset ja niitä vastaavat kestoiät.

\begin{tabular}{lccccc}
\hline Mitoitusmenetelmä & $\Delta \sigma \mathrm{w}[\mathrm{MPa}]$ & $\mathrm{m}$ & $\Delta \sigma(\mathrm{N}=2 \mathrm{e} 6)$ & $\Delta \sigma \mathrm{d}[\mathrm{MPa}]$ & $\mathrm{N}(\Delta \sigma \mathrm{d})$ \\
\hline Perusaine, $\mathrm{Rm}=832 \mathrm{MPa}$ & 182 & 4,38 & 263 & 100 & $\infty$ \\
$\mathrm{Rm}=832 \mathrm{MPa}, \mathrm{Kf}=2,53$ & 60 & 3,25 & 98 & 100 & 1906100 \\
$280 \mathrm{HV}, \mathrm{Kf}=2,53$ & 68 & 3,24 & 112 & 100 & 2890800 \\
$240 \mathrm{HV}, \mathrm{Kf}=2,53$ & 57 & 3,24 & 94 & 100 & 1651300 \\
Anthes Kf=2,82 & 53 & 3,17 & 88 & 100 & 1331400 \\
Lawrence, Kf=1,80 & 89 & 3,54 & 141 & 100 & 6743200 \\
IIW FAT 71 & 41,52 & 3 & 71 & 100 & 715800 \\
IIW FAT 225 (ENS) & 131,6 & 3 & 225 & 186 & 3540300 \\
Costa Domex 600 & 115,5 & 5,6 & 154 & 100 & $\infty$ \\
Sorger S690 & 158 & 4,1 & 234 & 100 & $\infty$ \\
Nykänen S1100 & 135,5 & 4,83 & 189 & 100 & $\infty$ \\
Murtumismek & 44,3 & - & - & 100 & 576034 \\
\hline
\end{tabular}

\section{Johtopäätökset}

Tutkimuksessa todettiin MAG-hitsatun päittäisliitoksen geometrian pienentävän väsymisrajan noin $33 \%$ : iin perusaineen väsymisrajaan verrattuna, kun paksuuden, kuormitustavan ja pinnanlaadun vaikutukset väsymisrajaan on huomioitu. Geometrian vaikutus määritettiin lovenvaikutusluvun avulla käyttäen selviytymistodennäköisyyttä $95 \%$. Hitsatun liitoksen geometrialla näyttää siten olevan hyvin suuri vaikutus liitoksen väsymiskestävyyteen.

Kun hitsauksen aiheuttama hitsialueen pehmeneminen huomioidaan kovuusmittausten perusteella, väsymisraja pienenee sallittua maksimilämmöntuontia käyttämällä noin $31 \%$ : iin perusaineen väsymisrajaan verrattuna. Pienentämällä hitsauksen lämmöntuontia viidenneksellä suositellusta maksimista väsymisraja pienenee noin $37 \%$ : iin perusaineeseen verrattuna. Siten lämmöntuonnin ja pehmenemisen vaikutukset väsymiskestävyyteen näyttävät olevan geometrian vaikutuksiin verrattuna vähäisempiä.

Aiempiin väsytyskoetuloksiin ja väsymisrajoihin verrattuna tässä tutkimuksessa hitsigeometrian perusteella määritetty $S-N$-käyrä on konservatiivinen etenkin suurilla kuormanvaihtokerroilla, vaikka hitsauksen aiheuttamaa jäännösjännitystilaa ei huomioida. Suunnitteluohjeiden FAT 71 mukaiseen käyrään verrattuna laskennallinen väsymisraja on hieman suurempi, jonka voidaan ajatella johtuvan materiaalin suuremmasta lujuudesta, sillä suunnitteluohjeet on tarkoitettu alun alkaen pehmeille teräksille.

MAG-hitsatun päittäisliitoksen väsymislujuuskäyrän määrittäminen lujuusopin sekä lovenvaikutuslukujen perusteella voi antaa kohtalaisia tuloksia, kun tarvitaan esimerkiksi alustavia mitoitustuloksia. Tällöin lovenvaikutusluvut on määritettävä riittävän tarkasti. Elementtimenetelmää käytettäessä on laskennassa käytettävä riittävän tiheää, maksimissaan $0,06 \mathrm{~mm}$ sivunmitalla olevaa elementtiverkkoa ja muita reunaehtoja niin, että laskentatilanne vastaa todellista kuormitustilannetta. 


\section{Lähteet}

[1] HM Miekk-oja, Metallioppi, Teknillisten tieteiden akatemia, Kustannusosakeyhtio Otava, Helsinki, (1960).

[2] TN Nguyen, MA Wahab. The effect of weld geometry and residual stresses on the fatigue of welded joints under combined loading, Journal of Materials Processing Tech. 77 (1998) 201-208. https://doi.org/10.1016/S0924-0136(97)00418-4

[3] T Teng, C Fung, P Chang. Effect of weld geometry and residual stresses on fatigue in butt-welded joints, International Journal of Pressure Vessels and Piping. 79 (2002) 467-482. https://doi.org/10.1016/s0308-0161(02)00060-1

[4] CM Sonsino. Effect of residual stresses on the fatigue behaviour of welded joints depending on loading conditions and weld geometry, International Journal of Fatigue. 31 (2009) 88-101. https://doi.org/10.1016/j.ijfatigue.2008.02.015

[5] GB Marquis, Z Barsoum, IIW recommendations for the HFMI treatment for improving the fatigue strength of welded joints, (2016). https://doi.org/10.1007/978-981-10-2504-4_1

[6] A Hobbacher, Recommendations for fatigue design of welded joints and components, Welding Research Council, New York, (2009).

[7] S Shen, INA Oguocha, S Yannacopoulos. Effect of heat input on weld bead geometry of submerged arc welded ASTM A709 Grade 50 steel joints, Journal of Materials Processing Tech. 212 (2012) 286-294. https://doi.org/10.1016/j.jmatprotec.2011.09.013

[8] H Remes, P Varsta. Statistics of Weld Geometry for Laser-Hybrid Welded Joints and its Application within Notch Stress Approach, Weld World. 54 (2010) R189R207. https://doi.org/10.1007/bf03263505

[9] S Liinalampi, H Remes, P Lehto, I Lillemäe, J Romanoff, D Porter. Fatigue strength analysis of laser-hybrid welds in thin plate considering weld geometry in microscale, International Journal of Fatigue. 87 (2016) 143-152. https://doi.org/10.1016/j.ijfatigue.2016.01.019

[10] JDM Costa, JAM Ferreira, LPM Abreu. Fatigue behaviour of butt welded joints in a high strength steel, Procedia Engineering. 2 (2010) 697-705. https://doi.org/10.1016/j.proeng.2010.03.075

[11] G Sorger, E Lehtimäki, S Hurme, H Remes, P Vilaça, L Molter. Microstructure and fatigue properties of friction stir welded high-strength steel plates, Science and Technology of Welding and Joining. 23 (2018) 380-386. https://doi.org/10.1080/13621718.2017.1399574

[12] T Nykänen, T Björk, R Laitinen. Fatigue strength prediction of ultra high strength steel butt-welded joints, Fatigue \& Fracture of Engineering Materials \& Structures. 36 (2013) 469-482. https://doi.org/10.1111/ffe.12015

[13] AF Hobbacher. The new IIW recommendations for fatigue assessment of welded joints and components - A comprehensive code recently updated, International Journal of Fatigue. 31 (2009) 50-58. https://doi.org/10.1016/j.ijfatigue.2008.04.002

[14] D Radaj, CM Sonsino, W Fricke. Recent developments in local concepts of fatigue assessment of welded joints, International Journal of Fatigue. 31 (2009) 2-11. https://doi.org/10.1016/j.ijfatigue.2008.05.019 
[15] T Nykänen, T Björk. A new proposal for assessment of the fatigue strength of steel butt-welded joints improved by peening (HFMI) under constant amplitude tensile loading, Fatigue \& Fracture of Engineering Materials \& Structures. 39 (2016) 566582. https://doi.org/10.1111/ffe. 12377

[16] K Ikonen, K Kantola, Murtumismekaniikka, Otatieto, Espoo, (1991).

[17] JW Cardinal, NASGRO Fatigue Crack Growth Analysis Software, (2006).

[18] B Moreno, A Martin, P Lopez-Crespo, J Zapatero, J Dominguez. On the Use of NASGRO Software to Estimate Fatigue Crack Growth under Variable Amplitude Loading in Aluminium Alloy 2024-T351, Procedia Engineering. 101 (2015) 302311. https://doi.org/10.1016/j.proeng.2015.02.037

[19] J Maierhofer, R Pippan, H Gänser. Modified NASGRO Equation for Short Cracks and Application to the Fitness-for-purpose Assessment of Surface-treated Components, Procedia Materials Science. 3 (2014) 930-935. https://doi.org/10.1016/j.mspro.2014.06.151

[20] J Maierhofer, R Pippan, H- Gänser. Modified NASGRO equation for physically short cracks, International Journal of Fatigue. 59 (2014) 200-207. https://doi.org/10.1016/j.ijfatigue.2013.08.019

[21] Yukitaka Murakami, Metal Fatigue: Effects of Small Defects and Nonmetallic Inclusions, Elsevier Science, GB, (2002).

[22] K Wallin, S Pallaspuro, I Valkonen, P Karjalainen-Roikonen, P Suikkanen. Fracture properties of high performance steels and their welds, Engineering Fracture Mechanics. 135 (2015) 219-231. https://doi.org/10.1016/j.engfracmech.2015.01.007

[23] SFS-EN-1993-1-12, Eurokoodi 3: Teräsrakenteiden suunnittelu. Osa 1-12: EN 1993 Laajennus teräslajeihin S700 asti. (2007).

[24] L Keränen. Kyntöauran rakenteiden kehittäminen mitatun kuormitusaineiston perusteella, Journal of Structural Mechanics. 50 (2017) 405-419. https://doi.org/10.23998/rm.64418

[25] T Nykänen, T Björk. Assessment of fatigue strength of steel butt-welded joints in as-welded condition - Alternative approaches for curve fitting and mean stress effect analysis, Mar.Struct. 44 (2015) 288-310. https://doi.org/10.1016/j.marstruc.2015.09.005

[26] AA Bhatti, I Barsoum, Z Barsoum, H Murakawa. Influence of thermo-mechanical material properties of different steel grades on welding residual stresses and angular distortion, Materials and Design. 65 (2015) 878-889. https://doi.org/10.1016/j.matdes.2014.10.019

[27] Rabb Roger, Väsyminen ja todennäköisyysteoria, Oulun yliopisto, Suomen Yliopistopaino Oy Juvenes Print, (2017).

[28] T Salmi, S Pajunen, Lujuusoppi, Pressus, Tampere, (2010).

[29] Radaj, C. M. Sonsino Sonsino, W. Fricke Fricke, W, Dieter, C. M, Fatigue Assessment of Welded Joints by Local Approaches, Woodhead Publishing Ltd, GB, (2006). https://doi.org/10.1533/9781845691882

[30] SSAB, Welding of Strenx, (2017).

[31] EJ Pavlina, CJ Van Tyne. Correlation of Yield Strength and Tensile Strength with Hardness for Steels, J. of Materi Eng and Perform. 17 (2008) 888-893. https://doi.org/10.1007/s11665-008-9225-5 
[32] SFS-EN 1993-1-9., Eurocode 3: Teräsrakenteiden suunnittelu. Osa 1-9: Väsyminen. (2005).

[33] SFS-EN ISO 5817, Hitsaus. Teräksen, nikkelin, titaanin ja niiden seosten sulahitsaus (paitsi sädehitsaus). Hitsiluokat. (2014).

[34] E Niemi, J Kemppi, Hitsatun rakenteen suunnittelun perusteet, Opetushallitus, Painatuskeskus, Helsinki, (1993).

[35] E Mikkola, Y Murakami, G Marquis. Fatigue Life Assessment of Welded Joints by the Equivalent Crack Length Method, Procedia Materials Science. 3 (2014) 1822-1827. https://doi.org/10.1016/j.mspro.2014.06.294

Lassi Keränen, Juhani Niskanen

Oulun yliopisto

Teknillinen tiedekunta

Materiaali- ja konetekniikan tutkimusyksikkö

Erkki Koiso-Kanttilan katu 5, PL 4200

90014 Oulun yliopisto

lassi-pekka.keranen@oulu.fi,juhani.niskanen@oulu.fi 